\title{
Expression profiling of nuclear receptors in breast cancer identifies TLX as a mediator of growth and invasion in triple-negative breast cancer
}

\author{
Meng-Lay Lin ${ }^{1, *}$, Hetal Patel ${ }^{1, *}$, Judit Remenyi ${ }^{2}$, Christopher R. S. Banerji ${ }^{3,4}$, Chun-Fui \\ Lai $^{1}$, Manikandan Periyasamy ${ }^{1}$, Ylenia Lombardo ${ }^{1}$, Claudia Busonero ${ }^{1}$, Silvia Ottaviani ${ }^{1}$, \\ Alun Passey ${ }^{1}$, Philip R. Quinlan ${ }^{5}$, Colin A. Purdie ${ }^{5}$, Lee B. Jordan ${ }^{5}$, Alastair M. Thompson ${ }^{6}$, \\ Richard S. Finn 7 , Oscar M. Rueda ${ }^{8}$, Carlos Caldas ${ }^{8}$, Jesus Gil ${ }^{9}$, R. Charles Coombes ${ }^{1}$, \\ Frances V. Fuller-Pace ${ }^{2}$, Andrew E. Teschendorff ${ }^{3,4}$, Laki Buluwela ${ }^{1}$, Simak Ali ${ }^{1}$ \\ ${ }^{1}$ Department of Surgery \& Cancer, Imperial College London, London, UK \\ ${ }^{2}$ Division of Cancer Research, University of Dundee, Ninewells Hospital \& Medical School, Dundee, UK \\ ${ }^{3}$ Statistical Genomics Group, UCL Cancer Institute, University College London, London, UK \\ ${ }^{4}$ Centre of Mathematics and Physics in Life \& Experimental Sciences, University College London, UK \\ ${ }^{5}$ Dundee Cancer Centre, Clinical Research Centre, University of Dundee, Ninewells Hospital \& Medical School, Dundee, UK \\ ${ }^{6}$ Department of Surgical Oncology, MD Anderson Cancer Center, Houston, USA \\ ${ }^{7}$ Geffen School of Medicine at UCLA, Los Angeles, CA USA \\ ${ }^{8}$ Cancer Research UK Cambridge Institute, University of Cambridge Li Ka Shing Centre, Cambridge, UK \\ ${ }^{9}$ Cell Proliferation Group, MRC Clinical Sciences Centre, Imperial College London, Hammersmith Campus, London, UK \\ *These authors have contributed equally to this work \\ Correspondence to: \\ Simak Ali, e-mail: simak.ali@imperial.ac.uk \\ Keywords: cancer, nuclear receptors, expression profiling, breast cancer, tumour classification \\ Received: March 11, $2015 \quad$ Accepted: April 30, $2015 \quad$ Published: May 13, 2015
}

\section{ABSTRACT}

The Nuclear Receptor (NR) superfamily of transcription factors comprises $\mathbf{4 8}$ members, several of which have been implicated in breast cancer. Most important is estrogen receptor-a (ERa), which is a key therapeutic target. ERa action is facilitated by co-operativity with other NR and there is evidence that ERa function may be recapitulated by other NRs in ERa-negative breast cancer. In order to examine the inter-relationships between nuclear receptors, and to obtain evidence for previously unsuspected roles for any NRs, we undertook quantitative RT-PCR and bioinformatics analysis to examine their expression in breast cancer. While most NRs were expressed, bioinformatic analyses differentiated tumours into distinct prognostic groups that were validated by analyzing public microarray data sets. Although ERa and progesterone receptor were dominant in distinguishing prognostic groups, other NR strengthened these groups. Clustering analysis identified several family members with potential importance in breast cancer. Specifically, RORY is identified as being co-expressed with ERa, whilst several NRs are preferentially expressed in ERa-negative disease, with TLX expression being prognostic in this subtype. Functional studies demonstrated the importance of TLX in regulating growth and invasion in ERa-negative breast cancer cells.

\section{INTRODUCTION}

Breast cancer is the most common cancer diagnosed in women, making up $23 \%$ of all cancers in women, with 1.38 million new cases worldwide annually and is responsible for 460,000 deaths [1]. The hormone estrogen is a key proliferative driver in breast cancer and acts by binding to estrogen receptor- $\alpha(\operatorname{ER} \alpha)$, resulting in its activation. Therefore, breast cancer patients are stratified on the basis of tumour expression 
of ER $\alpha$. Inhibition of ER $\alpha$ activity using the antagonist tamoxifen, or drugs that inhibit estrogen biosynthesis by blocking the activity of aromatase, a key enzyme in estrogen biosynthesis (e.g. anastrozole, letrozole) [2], provide important strategies for the management of ER $\alpha$ positive breast cancer and significantly reduce recurrence and breast cancer mortality.

Despite the benefits of endocrine agents for many patients, a large proportion of patients with ER $\alpha$-positive breast cancer progress on anti-estrogen or aromatase inhibitor therapies, or relapse following initial response [3, 4]. Moreover, current hormonal agents are ineffective for a fifth of breast cancers that do not express ER $\alpha$. These problems highlight the need for improvements in the understanding of ER $\alpha$-positive breast cancer, to develop additional markers that will identify those patients who will respond to hormone therapies, for developing new therapies for ER $\alpha$-positive patients who do not respond to current endocrine therapies and for identifying new agents to treat patients with ER $\alpha$ negative disease.

Nuclear receptors (NR) are typically activated upon binding to small molecules, including steroid hormones, retinoids, lipids and xenobiotics and play critical roles in growth, development, tissue homeostasis and metabolism [5]. Consequently, deregulation of NR action is important in many diseases, including cancer. Regulation of NR activity by small molecule ligands has facilitated the development of drugs that mimic the function of cognate ligands (agonists) or act as inhibitors (antagonists), a process that is further facilitated by the availability of ligand binding domain crystal structures for most NRs. Examples of antagonists as cancer therapeutics include inhibitors of estrogen (tamoxifen, fulvestrant), androgen (flutamide, bicalutamide, MDV3100) and progesterone (mifepristone, onapristone, lonaprisan) receptors. Therapeutic synthetic agonists and antagonists, many being approved for clinical use, have also been developed for many other NRs, including the glucocorticoid (GR; dexamethasone), vitamin D3 (VDR), retinoid, and peroxisome proliferator activated (PPARs) receptors [6]. Therefore, identification of NRs with functional roles in breast cancer development and progression has the potential for rapid progression to the clinic.

The progesterone receptor (PGR) is well-established as an ER $\alpha$-regulated gene Indeed, clinical practice includes the routine immunohistochemical determination of PGR; PGR expression is almost always observed only in ER $\alpha$ positive breast cancer [7] and its presence is a presumed marker of ER $\alpha$ functionality. Furthermore, increased risk of breast cancer has been reported for post-menopausal women with hormone replacement therapies (HRT) that include synthetic progestins [8]. Hence, anti-progestins have been tested in the metastatic setting [9] and clinical trials using the anti-progestin mifepristone in the early stage breast cancer setting are underway (ClinicalTrials. gov: NCT01138553).
Importantly, recent studies provide new evidence to show that some NRs act co-operatively with $\mathrm{ER} \alpha$ in breast cancer cells, often through co-regulation of gene expression. Thus, retinoic acid receptor- $\alpha(\operatorname{RAR} \alpha)$, whose expression is estrogen-regulated in breast cancer, localizes to ER $\alpha$ binding sites to modulate the expression of ER $\alpha$ target genes [10, 11], establishing crosstalk between estrogen and retinoid signalling that is important for the growth of ER $\alpha$-positive breast cancer cells. LRH-1 is another ER $\alpha$-regulated NR, which stimulates proliferation and promotes motility and invasion of breast cancer cells and regulates the expression of estrogen-responsive genes in $\mathrm{ER} \alpha+$ breast cancer cells, acting in a co-operative manner with $\mathrm{ER} \alpha$ [12].

The androgen receptor (AR), another NR whose expression is strongly associated with ER $\alpha$ expression in breast cancer [13], inhibits expression of estrogen responsive genes in ER $\alpha$-positive breast cancer cells. Remarkably, in a small subset of ER $\alpha$-negative "molecular apocrine" breast cancer [14], AR activates, rather than inhibits, the expression of many ER $\alpha$ target genes through its recruitment to sites that are normally bound by ER $\alpha$ in luminal MCF7 cells [15], suggesting that in ER $\alpha$-negative breast cancer some NRs can, at least in part, take the role of ER $\alpha$.

It appears, therefore, that NRs co-expressed with $\mathrm{ER} \alpha$ play important roles in the regulation of gene expression by ER $\alpha$ and consequently in breast cancer, whilst other NRs have been implicated in ER $\alpha$-negative breast cancer $[16,17]$. These findings prompted us to determine the expression profiles of all NRs in different breast cancer subtypes using quantitative RT-PCR (qRTPCR). Our analysis confirms the co-expression of several NRs with $\mathrm{ER} \alpha$, but also identifies other NRs whose expression is strongly associated with $\mathrm{ER} \alpha$, in particular a previously unreported relationship with retinoic acid receptor-related orphan receptor- $\gamma(\operatorname{ROR} \gamma)$. Further, we show that expression of the Tailless homolog TLX (NR2E1) is negatively associated with $\mathrm{ER} \alpha$, TLX being expressed in ER $\alpha$-negative breast cancer and confirm this relationship through analysis of published microarray data sets. Functional studies demonstrate that TLX regulates breast cancer cell growth and invasion, identifying TLX as a new therapeutic target in breast cancer.

\section{RESULTS}

\section{Quantitative RT-PCR profiling demonstrates expression of the majority of nuclear receptors in breast cancer}

To determine the NR expression profiles in tumours representative of different breast cancer subtypes, total RNA was prepared from 128 breast tumours from the Tayside Tissue Bank, for which clinical and histopathological details were available, 
as well as long term clinical follow-up. For qRT-PCR, we designed a Taqman TLDA card, to include assays for $47 \mathrm{NR}$, together with GAPDH as a control. This arrangement excluded an assay for COUP-TF1 (NR2F1), since the only real-time assays available for COUP-TF1 at the time also detect COUP-TF2 (NR2F2). Most NRs were expressed in this patient cohort, with $\mathrm{ER} \alpha, \mathrm{RAR} \alpha$, EAR2, COUP-TF2 and RXR $\beta$ being the most highly expressed NRs (Figure 1). Interestingly, COUP-TF2 and EAR2 expression levels were high in ER $\alpha$-positive, as well as ER $\alpha$-negative tumours (Table 1; Supplementary Figures 1-2). Although more highly expressed in ER $\alpha$ positive breast cancer, high-level $\operatorname{RAR} \alpha$ expression was also evident in ER $\alpha$-negative tumours. Expression of CAR, SHP and FXR was undetectable in the great majority of cases.

\section{Consensus cluster analysis to differentiate breast cancers in different groups}

Unsupervised hierarchical consensus clustering [18] was used to discern molecular subclasses of breast tumours with similar NR expression profiles. Consensus cluster analysis provided evidence for separation of the tumours into two, three or four clusters (Supplementary Figure 3), with two clusters exhibiting the most stable configuration (Figure 2A). For the two clusters, Kaplan-Meier (KM) survival plots showed that patients segregating to cluster 2 have a significantly better prognosis, compared with patients in cluster $1(\mathrm{HR}=2.55$ (1.06-6.12), $p=0.029$ ) (Figure 2B). Determination of the association of the two clusters with clinical features showed that cluster 2 samples were likely to be of lower

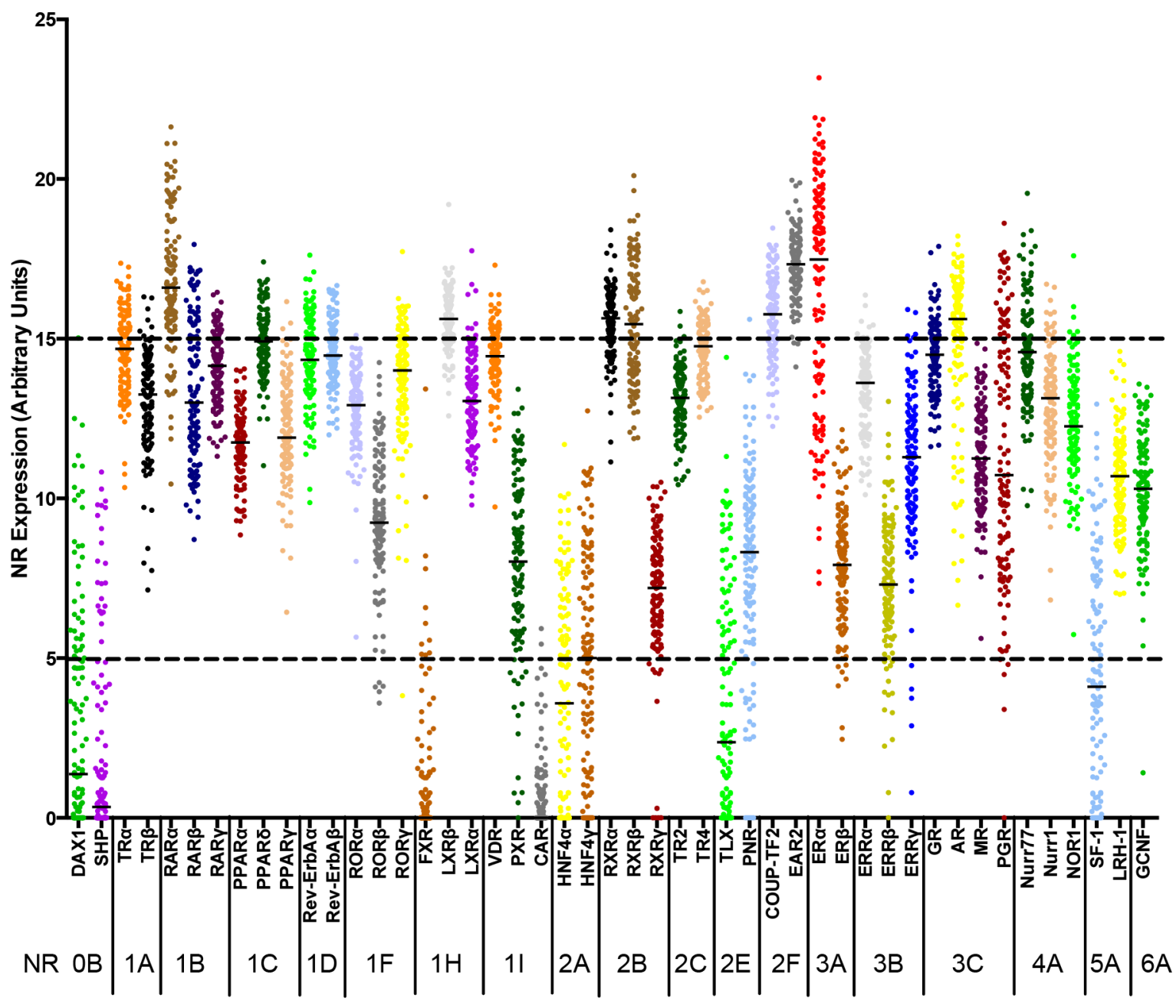

Figure 1: Relative expression of Nuclear Receptors in RNA prepared from breast tumours. The normalized mRNA expression of each NR is shown for RNAs prepared from 128 breast tumours. Each dot represents one patient sample. Real-time RT-PCR was performed for all NR, excepting COUP-TF1. The NRs are ordered using the NR superfamily nomenclature: 0B, DAX-like receptors; 1A, Thyroid Hormone Receptors; 1B, Retinoic acid receptors; 1C, Peroxisome proliferator-activated receptors; 1D, Rev-Erb receptors; 1F, RAR-related orphan receptors; 1H, Liver X receptor-like receptors; 1I, Vitamin D receptor-like receptors; 2A, Hepatocyte nuclear factor-4 receptors; 2B, Retinoid X receptors; 2C, Testicular receptors; 2E, Tailless-like receptors; 2F, COUP-TF-like receptors; 3A, Estrogen receptors; 3B, Estrogenrelated receptors; 3C, 3-Ketosteroid receptors; 4A, Nerve growth factor IB-like receptors; 5A, Fushi tarazu F1-like receptors; 6A, Germ cell nuclear factor receptors. 
Table 1: Expression levels of nuclear receptors in 128 breast cancers

\begin{tabular}{|c|c|c|c|c|c|c|c|}
\hline \multicolumn{2}{|c|}{ High expression } & \multicolumn{4}{|c|}{ Moderate expression $(15>$ to $>5)$} & \multicolumn{2}{|c|}{ Low/Absent expression $(\leq 5)$} \\
\hline \multicolumn{8}{|c|}{ All Tumors } \\
\hline $\mathbf{E R} \boldsymbol{\alpha}$ & $\begin{array}{c}17.49(13.55- \\
19.36)\end{array}$ & PPAR $\delta$ & $\begin{array}{c}14.92(14.24- \\
15.45)\end{array}$ & $\mathbf{R O R \alpha}$ & $12.93(12.19-13.57)$ & SF-1 & $4.11(0.73-7.28)$ \\
\hline EAR2 & $\begin{array}{c}17.34(16.77- \\
17.93)\end{array}$ & TR4 & $\begin{array}{c}14.77(14.00- \\
15.42)\end{array}$ & NOR1 & $12.26(11.33-13.37)$ & HNF4 $\alpha$ & $3.59(-0.10-6.65)$ \\
\hline $\mathbf{R A R} \alpha$ & $\begin{array}{c}16.61(15.58- \\
18.06)\end{array}$ & $\operatorname{TR} \alpha$ & $\begin{array}{c}14.69(13.82- \\
15.52)\end{array}$ & $\operatorname{PPAR} \gamma$ & $11.91(11.22-13.06)$ & TLX & $2.38(0.02-6.21)$ \\
\hline $\begin{array}{l}\text { COUP- } \\
\text { TF2 }\end{array}$ & $\begin{array}{c}\mathbf{1 5 . 7 7}(14.85- \\
16.62)\end{array}$ & Nurr77 & $\begin{array}{c}14.59(13.49- \\
15.57)\end{array}$ & PPAR $\alpha$ & $11.75(11.20-12.34)$ & DAX1 & $1.38(-0.58-5.24)$ \\
\hline $\mathbf{R X R} \alpha$ & $\begin{array}{c}\mathbf{1 5 . 6 5}(15.01- \\
16.27)\end{array}$ & GR & $\begin{array}{c}\mathbf{1 4 . 5 1}(13.67- \\
15.24)\end{array}$ & $\mathbf{E R R} \gamma$ & $11.30(9.83-12.58)$ & SHP & $0.34(-0.77-3.42)$ \\
\hline LXRß & $\begin{array}{c}15.62(15.10- \\
16.21)\end{array}$ & Rev-ErbAß & $\begin{array}{c}14.48(13.96- \\
15.19)\end{array}$ & MR & $11.26(10.13-12.6)$ & FXR & $-0.07(-1.06-1.33)$ \\
\hline AR & $\begin{array}{c}\mathbf{1 5 . 6 2}(14.19- \\
16.36)\end{array}$ & VDR & $\begin{array}{c}14.46(13.99- \\
15.00)\end{array}$ & PGR & $10.74(8.10-15.15)$ & CAR & $-0.11(-1.07-0.78)$ \\
\hline \multirow[t]{9}{*}{ RXRB } & $\begin{array}{c}\mathbf{1 5 . 4 6}(14.01- \\
17.00)\end{array}$ & Rev-ErbAa & $\begin{array}{c}14.35(13.52- \\
15.39)\end{array}$ & LRH-1 & $10.70(9.41-11.63)$ & & \\
\hline & & $\mathbf{R A R} \gamma$ & $\begin{array}{c}14.15(13.34- \\
14.90)\end{array}$ & GCNF & $10.31(9.33-11.39)$ & & \\
\hline & & $\operatorname{ROR} \gamma$ & $\begin{array}{c}14.01(12.84- \\
14.95)\end{array}$ & RORß & $9.25(8.22-10.75)$ & & \\
\hline & & $\mathbf{E R R} \alpha$ & $\begin{array}{c}13.62(12.33- \\
14.28)\end{array}$ & PNR & $8.33(6.30-10.05)$ & & \\
\hline & & TRß & $\begin{array}{c}13.26(12.11- \\
14.30)\end{array}$ & PXR & $8.03(6.24-10.13)$ & & \\
\hline & & TR2 & $\begin{array}{c}13.15(12.53- \\
13.81)\end{array}$ & ERß & $7.93(6.66-8.94)$ & & \\
\hline & & NURR1 & $\begin{array}{c}13.14(11.91- \\
14.00)\end{array}$ & ERRß & $7.31(6.28-8.71)$ & & \\
\hline & & $\mathbf{L X R} \alpha$ & $\begin{array}{c}13.05(12.06- \\
14.09)\end{array}$ & $\mathbf{R X R} \gamma$ & $7.20(6.01-8.24)$ & & \\
\hline & & RARß & $\begin{array}{c}13.00(11.71- \\
15.30)\end{array}$ & HNF4 $\gamma$ & $5.01(1.39-7.77)$ & & \\
\hline
\end{tabular}

\section{ERo-positive}

\begin{tabular}{|c|c|c|c|c|c|c|c|}
\hline ERa & $\begin{array}{c}18.7(17.24- \\
19.95)\end{array}$ & PPARס & $\begin{array}{c}14.93(14.27- \\
15.48)\end{array}$ & $\mathbf{R O R \alpha}$ & $13.02(12.50-13.71)$ & HNF4 $\gamma$ & $4.97(1.43-8.16)$ \\
\hline EAR2 & $\begin{array}{c}17.52(17.03- \\
18.03)\end{array}$ & $\operatorname{TR\alpha }$ & $\begin{array}{c}14.90(14.29- \\
15.74)\end{array}$ & RARß & $12.91(11.54-15.21)$ & HNF4a & $4.11(0.24-6.84)$ \\
\hline $\mathbf{R A R} \alpha$ & $\begin{array}{c}17.24(15.91- \\
18.84)\end{array}$ & TR4 & $\begin{array}{c}14.86(14.06- \\
15.48)\end{array}$ & NOR1 & $12.40(11.51-13.49)$ & SF-1 & $3.57(0.55-6.65)$ \\
\hline LXRß & $\begin{array}{c}15.95(15.29- \\
16.43)\end{array}$ & Nurr77 & $\begin{array}{c}14.78(13.97- \\
16.27)\end{array}$ & PPAR $\gamma$ & $12.10(11.40-13.10)$ & TLX & $0.86(-0.51-3.56)$ \\
\hline
\end{tabular}

(Continued) 


\begin{tabular}{|c|c|c|c|c|c|c|c|}
\hline \multicolumn{3}{|c|}{ High expression } & \multicolumn{3}{|c|}{ Moderate expression $(15>$ to $>5)$} & \multicolumn{2}{|c|}{ Low/Absent expression $(\leq 5)$} \\
\hline $\begin{array}{l}\text { COUP- } \\
\text { TF2 }\end{array}$ & $\begin{array}{c}15.93(15.11- \\
16.78)\end{array}$ & Rev-ErbAß & $\begin{array}{c}14.72(14.06- \\
15.42)\end{array}$ & PPARa & $11.52(11.07-12.07)$ & DAX1 & $0.69(-0.67-4.61)$ \\
\hline AR & $\begin{array}{c}15.88(15.15- \\
16.56)\end{array}$ & GR & $\begin{array}{c}14.60(13.98- \\
15.33)\end{array}$ & ESRRG & $11.31(10.25-12.38)$ & SHP & $0.56(-0.67-3.8)$ \\
\hline $\operatorname{RXR} \alpha$ & $\begin{array}{c}15.87(15.37- \\
16.35)\end{array}$ & VDR & $\begin{array}{c}14.58(14.08- \\
15.00)\end{array}$ & MR & $11.26(10.17-12.65)$ & FXR & $0.1(-0.75-1.31)$ \\
\hline RXRß & $\begin{array}{c}15.37(14.10- \\
17.44)\end{array}$ & Rev-ErbA $\alpha$ & $\begin{array}{c}14.51(13.90- \\
15.63)\end{array}$ & LRH-1 & $11.01(9.83-11.74)$ & CAR & $0.1(-0.86-0.79)$ \\
\hline & & $\mathbf{R A R} \gamma$ & $\begin{array}{c}14.46(13.79- \\
15.13)\end{array}$ & GCNF & $10.40(9.39-11.67)$ & & \\
\hline & & $\mathbf{R O R} \gamma$ & $\begin{array}{c}14.35(13.45- \\
15.08)\end{array}$ & RORß & $9.75(8.81-11.46)$ & & \\
\hline & & PGR & $\begin{array}{c}13.98(10.34- \\
15.81)\end{array}$ & PNR & $9.38(7.87-10.60)$ & & \\
\hline & & TRß & $\begin{array}{c}13.61(12.45- \\
14.42)\end{array}$ & ERß & $7.90(6.55-8.87)$ & & \\
\hline & & $\mathbf{E R \alpha}$ & $\begin{array}{c}13.49(12.33- \\
14.27)\end{array}$ & PXR & $7.88(6.30-10.19)$ & & \\
\hline & & NURR1 & $\begin{array}{c}13.34(12.40- \\
14.21)\end{array}$ & ERRß & $7.86(6.81-8.97)$ & & \\
\hline & & TR2 & $\begin{array}{c}13.27(12.82- \\
14.02)\end{array}$ & $\mathbf{R X R} \gamma$ & $7.60(6.19-8.66)$ & & \\
\hline & & LXRa & $\begin{array}{c}13.10(12.12- \\
14.07)\end{array}$ & & & & \\
\hline
\end{tabular}

\section{ERo-negative}

\begin{tabular}{|c|c|c|c|c|c|c|c|}
\hline EAR2 & $\begin{array}{c}16.89(16.15- \\
17.46)\end{array}$ & PPAR $\delta$ & $\begin{array}{c}14.91(14.2- \\
15.34)\end{array}$ & ERa & $12.14(11.18-13.55)$ & DAX1 & $4.54(-0.08-6.06)$ \\
\hline RARa & $\begin{array}{c}15.54(13.79- \\
16.64)\end{array}$ & TR4 & $\begin{array}{c}14.59(13.91- \\
14.92)\end{array}$ & NURR1 & $12.12(11.12-13.36)$ & HNF4a & $2.36(-0.43-5.82)$ \\
\hline RXRß & $\begin{array}{c}15.49(13.89- \\
16.51)\end{array}$ & VDR & $\begin{array}{c}14.29(13.41- \\
14.93)\end{array}$ & NOR1 & $11.89(11.27-13.14)$ & SHP & $-0.18(-1.35-2.63)$ \\
\hline $\begin{array}{l}\text { COUP- } \\
\text { TF2 }\end{array}$ & $\begin{array}{c}15.37(14.22- \\
15.96)\end{array}$ & GR & $\begin{array}{c}14.23(13.28- \\
14.83)\end{array}$ & PPARG & $11.50(10.94-12.96)$ & FXR & $-0.27(-1.73-1.26)$ \\
\hline LXRß & $\begin{array}{c}15.29(14.72- \\
15.73)\end{array}$ & Rev-ErbAB & $\begin{array}{c}14.15(13.53- \\
14.56)\end{array}$ & MR & $11.25(10.05-12.46)$ & CAR & $-0.27(-1.67-0.64)$ \\
\hline \multirow[t]{4}{*}{$\mathbf{R X R \alpha}$} & $\begin{array}{c}14.99(14.37- \\
15.53)\end{array}$ & $\operatorname{TR} \alpha$ & $\begin{array}{c}14.06(13.08- \\
15.15)\end{array}$ & ERR $\gamma$ & $10.87(9.12-13.03)$ & & \\
\hline & & Nurr77 & $\begin{array}{c}13.88(13.16- \\
14.65)\end{array}$ & LRH-1 & $9.94(8.80-10.96)$ & & \\
\hline & & Rev-ErbA $\alpha$ & $\begin{array}{c}13.81(13.26- \\
14.63)\end{array}$ & GCNF & $9.72(8.76-10.85)$ & & \\
\hline & & ERRa & $\begin{array}{c}13.70(12.92- \\
14.41)\end{array}$ & PXR & $8.49(6.21-9.84)$ & & \\
\hline
\end{tabular}

(Continued) 


\begin{tabular}{|c|c|c|c|c|c|}
\hline \multicolumn{2}{|l|}{ High expression } & \multicolumn{3}{|c|}{ Moderate expression $(15>$ to $>5)$} & \multirow[t]{2}{*}{ Low/Absent expression $(\leq 5)$} \\
\hline & $\mathbf{A R}$ & $\begin{array}{c}13.68(10.70- \\
15.70)\end{array}$ & RORß & $8.26(7.08-9.37)$ & \\
\hline & $\mathbf{R A R} \gamma$ & $\begin{array}{c}13.58(13.02- \\
14.10)\end{array}$ & PGR & $8.06(7.05-9.69)$ & \\
\hline & RARB & $\begin{array}{c}13.47(12.31- \\
15.41)\end{array}$ & ERß & $8.01(6.78-9.17)$ & \\
\hline & LXRa & $\begin{array}{c}13.03(11.99- \\
14.24)\end{array}$ & $\mathbf{R X R} \gamma$ & $6.40(5.76-7.21)$ & \\
\hline & $\operatorname{ROR} \gamma$ & $\begin{array}{c}12.98(12.32- \\
14.20) \\
\end{array}$ & TLX & $6.29(3.80-8.40)$ & \\
\hline & TR2 & $\begin{array}{c}12.61(11.83- \\
13.47)\end{array}$ & ERRß & $6.14(5.14-7.35)$ & \\
\hline & TRß & $\begin{array}{c}12.55(11.10- \\
13.40)\end{array}$ & PNR & $5.41(3.12-7.34)$ & \\
\hline & RORa & $\begin{array}{c}12.50(11.78- \\
13.33)\end{array}$ & SF-1 & $5.03(2.32-7.48)$ & \\
\hline & PPAR $\alpha$ & $\begin{array}{c}12.26(11.72- \\
12.75)\end{array}$ & HNF4 $\gamma$ & $5.03(1.15-7.28)$ & \\
\hline
\end{tabular}

Expression levels ( $\Delta \mathrm{Ct}$ values) relative to undetectable expression $(\mathrm{Ct}>35)$. Median expression is shown, together with the 25 and 75 percentile range.

tumour grade ( $p=0.001$ ), although tumour grade trended towards, but did not reach significant association with survival in this patient cohort (Supplementary Figure 4). Moreover, there was an association between the clusters and immunohistochemically (IHC) determined $\mathrm{ER} \alpha(p=$ 4.1E-14) and PGR ( $p=1.4 \mathrm{E}-12)$ status (Figure 2A), with the better prognosis group (cluster 2) being enriched in ER $\alpha$ and PGR positive tumours. There was no relationship between the clusters and HER2 status $(p=1.0)$ and although patients with PGR positive disease had better survival than PGR negative patients, this also did not reach significance $(p=0.113)$ in our patient cohort (Supplementary Figure 5). Patients with IHC determined ER $\alpha$-positivity had a better prognosis than the ER $\alpha$ negative patients $(\mathrm{HR}=0.41(0.18-0.91) ; p=0.024)$.

We have seen that ER $\alpha$ and PGR mRNA levels were not associated with patient outcome in univariate analysis, regardless of the expression level cut-offs used, suggesting that other NRs are important contributors to the survival differences observed for the two clusters, at least when examining expression at the mRNA level. To investigate this, we used unsupervised consensus clustering analysis with different partitions, $k=2$ to $k=6$, in order to cluster NR gene expression (Supplementary Figure 5). The empirical cumulative distribution function indicated an approximate best stability for $k=3$, indicating that the optimal number of robust NR clusters in this data set is three (Figure 2C). Gene Cluster B, which contained ER $\alpha$, also contained the known ER $\alpha$-regulated genes PGR,
RAR $\alpha$ and LRH-1. This cluster also contained AR and PNR, both previously shown to be co-expressed with ER $\alpha$ in breast cancer $[13,19]$, as well as ERR $\gamma$. High-level ERR $\gamma$ expression has previously been associated with ER $\alpha$ and PGR-positivity, although the statistical significance of the previously reported associations was weak ( $p=0.054$ and $p=0.045$, respectively) [20]. Also present in the ER $\alpha$ cluster were TRß, ROR $\beta$, and ROR $\gamma$. The Kruskal-Wallis test, used to determine association between ER $\alpha$, PGR and HER2 IHC status and PGR ( $p=1.10 \mathrm{E}-14), \mathrm{AR}(p=$ 8.86E-07), RAR $\alpha(p=7.07 \mathrm{E}-06)$, LRH-1 $(p=1.44 \mathrm{E}-03)$, as well as TRß $(p=3.06 \mathrm{E}-04), \operatorname{ROR} \beta(p=2.70 \mathrm{E}-03)$ and $\operatorname{ROR} \gamma(p=1.18 \mathrm{E}-04)$ mRNA expression provides further evidence in support of the association between expression of these receptors and ER $\alpha$ (Supplementary Figures 1-2). The Mann-Whitney test further confirmed association between the expression of these NRs and ER $\alpha$ (Table 2). It should be noted that despite the co-clustering of ERR $\gamma$ with ER $\alpha$, the association for ERR $\gamma$ did not reach significance $(p=0.603)$.

To obtain further evidence for the association between ER $\alpha$ expression and expression of these NRs, we analysed a number of gene expression microarray data sets. The data sets used were chosen on the basis of patient number and/or availability of follow-up information on outcome and included the METABRIC series of nearly 2,000 cases [21], the TCGA series of about 500 cases [22] and the $300+$ cases in GSE20685 [23]. As expected, there were highly statistically 

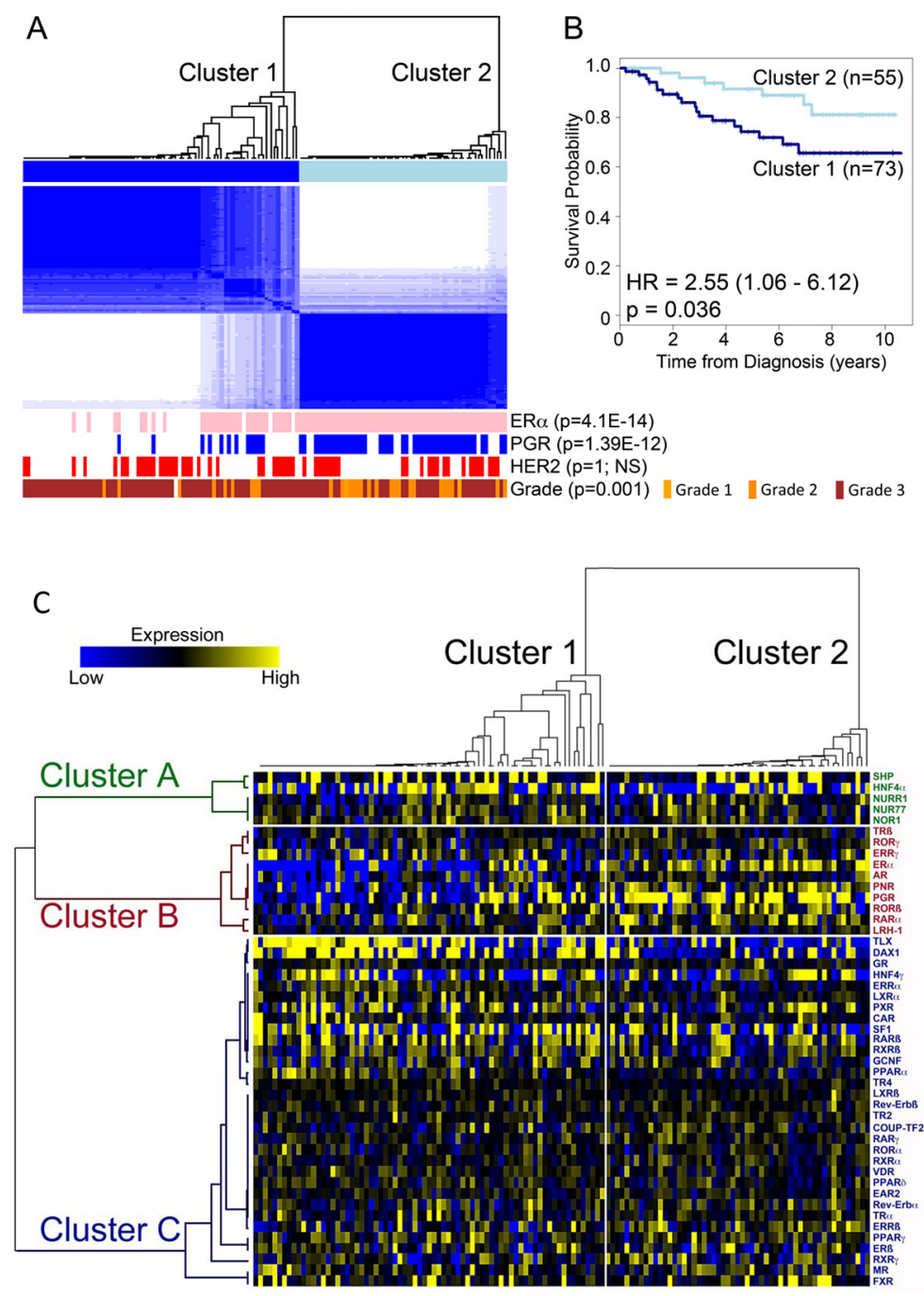

Figure 2: Identification of two main breast cancer subtypes based on NR gene expression. A. Unsupervised hierarchical consensus clustering segregates tumours into two clusters based on qRT-PCR for NR expression. Shown is the ER $\alpha$, PGR and HER2 IHC status for each tumour, positive tumours being depicted as pink (ER $\alpha$ ), blue (PGR) and red (HER2) bars. Statistical significance was established using Fisher's exact test. B. Kaplan-Meier plot shows patient survival for the patients in the two clusters. Crosses show censored samples. C. Heatmap representation of hierarchical consensus cluster analysis of nuclear receptor mRNA expression. Tumours are grouped according to the two clusters identified from consensus clustering. Median centred NR expression in patient samples is shown in a heat map following the arrangement of NRs and tumour samples according to the clusters identified in the consensus cluster analysis.

significant positive associations between ER $\alpha$ IHC status and ER $\alpha$ mRNA levels, as well as with PGR, AR and RAR $\alpha$ (Table 2). Of the other NRs co-clustering with ER $\alpha$ in our qRT-PCR samples, evidence for coexpression of ER $\alpha$ with TR $\beta, E R R \gamma$, ROR $\beta$ or LRH-1 was less equivocal, not reaching statistical significance in one out of the three microarray datasets. However, association between ER $\alpha$ and PNR expression was evident, as previously reported [19]. The association between ER $\alpha$ and ROR $\gamma$, which has not previously been described, was confirmed in the microarray series. Expression of ROR $\gamma$ in breast cancer cells was determined by expression analysis in breast cancer cell lines (Figure 6A), which also showed association of $\mathrm{ROR} \gamma$ with ER $\alpha$ expression (Mann-Whitney; $p=0.014$ ).

\section{Identification of nuclear receptors for distinguishing patient groups}

We next determined if the consensus clustering signature generated from the qRT-PCR analysis that separates our patient cohort into good and poor prognosis groups, could be extended to the microarray data sets. To do this, we performed Random Forest (RF) classification [24] with the tumour cluster classification obtained from consensus clustering as categorical factors to generate a model using z-score transformed qRT-PCR data set. As the number of trees may affect classification error, RF analysis was carried out for 5000, 10000, 20000 and 50000 trees, with the best error stability being exhibited for 50,000 trees (Figure 3A). We then validated this classifier with 
Table 2: Association between ER $\alpha$ and Select NR expression (Mann-Whitney)

\begin{tabular}{|c|c|c|c|c|}
\hline & qRT-PCR & METABRIC* & TCGA $\mathbf{A}^{\#}$ & GSE20685 $^{\S}$ \\
\hline Sample No. Analysed & $n=128$ & $n=1,980$ & $n=485$ & $n=327$ \\
\hline $\mathrm{ER} \alpha$ & $3.6 \mathrm{E}-18$ & $2.4 \mathrm{E}-188$ & $2.8 \mathrm{E}-47$ & $9.6 \mathrm{E}-48$ \\
\hline PGR & $4.6 \mathrm{E}-11$ & $9.6 \mathrm{E}-102$ & $1.7 \mathrm{E}-29$ & $6.4 \mathrm{E}-34$ \\
\hline \multirow[t]{2}{*}{ PNR } & $1.9 \mathrm{E}-10$ & 4.9E-110 & $1.8 \mathrm{E}-34$ & $1.5 \mathrm{E}-11$ \\
\hline & $\mathrm{AR}$ & 7.6E-60 & $7.8 \mathrm{E}-28$ & $8.0 \mathrm{E}-16$ \\
\hline $\mathrm{ROR} ß$ & $1.9 \mathrm{E}-06$ & $1.7 \mathrm{E}-06$ & $1.2 \mathrm{E}-02$ & $3.4 \mathrm{E}-01$ \\
\hline RAR $\alpha$ & $1.3 \mathrm{E}-06$ & $3.0 \mathrm{E}-88$ & $1.2 \mathrm{E}-24$ & $1.3 \mathrm{E}-07$ \\
\hline TRß & $9.2 \mathrm{E}-05$ & $8.1 \mathrm{E}-01$ & $1.7 \mathrm{E}-08$ & $1.4 \mathrm{E}-08$ \\
\hline $\mathrm{ROR} \gamma$ & $2.6 \mathrm{E}-04$ & $2.3 \mathrm{E}-44$ & $1.5 \mathrm{E}-15$ & 7.3E-08 \\
\hline LRH-1 & $1.9 \mathrm{E}-03$ & 4.1E-03 & $5.8 \mathrm{E}-04$ & $2.9 \mathrm{E}-01$ \\
\hline ERR $\gamma$ & $6.0 \mathrm{E}-01$ & $1.8 \mathrm{E}-05$ & 4.4E-02 & $3.1 \mathrm{E}-01$ \\
\hline
\end{tabular}

Negative Association with ER $\alpha$

\begin{tabular}{|l|c|c|c|c|}
\hline & qRT-PCR & METABRIC & TCGA & GSE20685 \\
\hline TLX & $5.5 \mathrm{E}-07$ & $2.7 \mathrm{E}-10$ & $1.6 \mathrm{E}-15$ & $1.3 \mathrm{E}-02$ \\
\hline PPAR $\alpha$ & $3.3 \mathrm{E}-04$ & $1.1 \mathrm{E}-34$ & $4.3 \mathrm{E}-28$ & $1.4 \mathrm{E}-12$ \\
\hline DAX1 & $2.9 \mathrm{E}-02$ & $1.7 \mathrm{E}-02$ & $4.0 \mathrm{E}-03$ & $6.7 \mathrm{E}-01$ \\
\hline
\end{tabular}

*21 samples were excluded because of lack of follow-up information

\#51 samples were removed from analysis due to incomplete information or sample duplication

${ }^{\S} \mathrm{ER} \alpha$ status is based on cut-offs for ER $\alpha$ positivity determined from the microarray expression profiling data by the authors [44]. For the other data sets IHC determined ER $\alpha$ status has been applied for the analysis.

two data sets, GSE20685 [23], which included patient survival information for 327 samples and the METABRIC samples $(n=1,959)$. In both cases, cluster 2 was significantly associated with better prognosis $(\mathrm{HR}=2.32$ (1.36-3.95), $p=0.002$ and $\mathrm{HR}=1.86(1.51-12.30), p=$ $5.1 \times 10^{-9}$, respectively) (Figure 3B). This indicates that the NR expression signature derived from our qRT-PCR analysis separates breast tumours into two prognostically different groups, although given the significantly greater number of ER $\alpha$ and PGR positive tumours in cluster 2, it is likely that $E R \alpha$ and PGR are important determinants in this expression signature. Indeed, plotting variable importance showed that ER $\alpha$ and PGR are especially important, but also highlighted several other NRs as important classifiers of clusters 1 and 2 (Figure 3C). To further confirm the important variables, RF was run re-iteratively for NRs, removing the bottom most NR (assigned the least variable importance score), one at a time. This showed that the top 8 NR, namely ER $\alpha$, PGR, DAX1, TLX, PNR, RAR $\gamma$, RAR $\alpha$ and Rev-erbAß provide the lowest error rate (Figure 3D), highlighting these NRs as the most important variables for differentiating the two tumour clusters.
We next used Pairwise Pearson correlation coefficient (PCC) to further define relationships between NRs. PCC confirmed associations between groups of NRs, particularly for NRs in the ER $\alpha$ cluster, as well as a close relationship for the NR4A receptors, NURR1, NUR77 and NOR1 (Figure 4). Of particular note is the fact that expression of TLX, identified as an important variable in the Random Forest analysis, was negatively associated with ER $\alpha$ mRNA expression $(\mathrm{PCC}=-0.37, p$-value $=$ 1.97E-05). TLX expression was also negatively associated with clinical ER $\alpha$ (IHC) status ( $p=5.5 \mathrm{E}-07$; Table 2). However, evidence for association of DAX1 expression with $\mathrm{ER} \alpha$ status $(p=2.9 \mathrm{E}-02)$ and $\mathrm{ER} \alpha$ mRNA $(\mathrm{PCC}=$ $-0.10, p=\mathrm{NS}$ ) was seen to be weak. Nor did examination of the microarray data indicate an association between $\mathrm{ER} \alpha$ and DAX1. By contrast, the negative association between ER $\alpha$ and TLX was confirmed in the METABRIC $(p=5.5 \mathrm{E}-07)$ and $\operatorname{GSE} 20685(p=1.3 \mathrm{E}-02)$ datasets. As $\mathrm{ER} \alpha$ is a positive prognostic factor in breast cancer, TLX expression might be expected to be associated with poor outcome. Survival analyses showed that TLX expression in breast cancer is indeed associated with poor survival in the GSE20685 $(\mathrm{HR}=1.77(1.12-2.79), p=0.0137)$ 

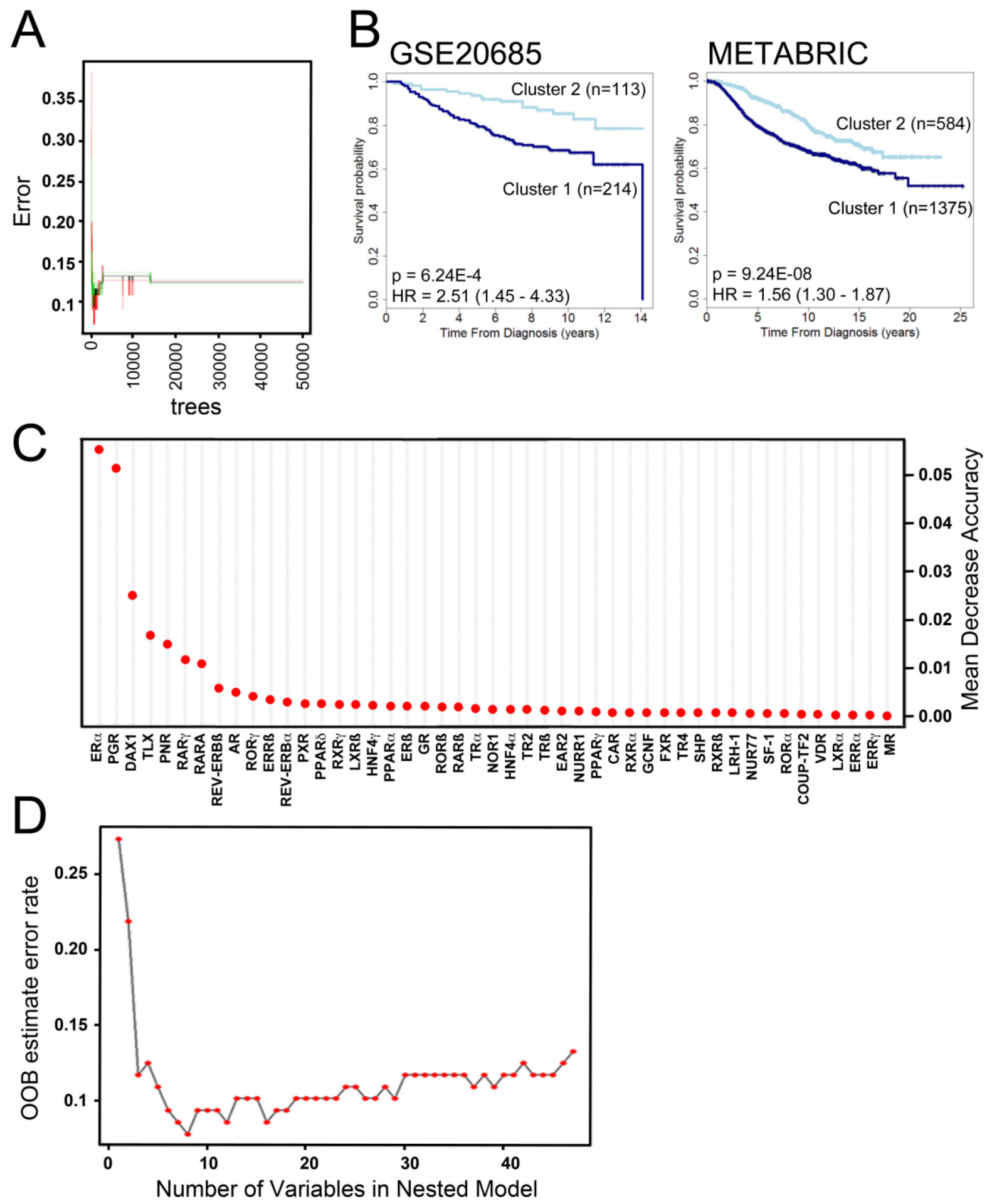

Figure 3: Random Forest (RF) analysis to generate a classification model for risk groups identifies NR of highest importance in generating breast cancer clusters. A. Shown is an error rate plot for 50,000 trees generated. The curves represent the error rates for cluster 1 (red), cluster 2 (green) and the "Out-of-Bag $(\mathrm{OOB})$ error rate (black). B. Kaplan-Meier plot shows association of the NR expression signature identified by RF analysis with disease specific survival for the GSE20685 (26) and METABRIC (28) microarray data sets. C. Dot chart of NR importance as measured by RF analysis. D. Shown is OOB error for 50,000 RF trees. The red dots represent the OOB errors for the number of NRs using in RF, each analysis excluding the least important NR. Thus, in the case of $8 \mathrm{NR}$, which yields the lowest error, only the top 8 NR from part B were used for RF. 


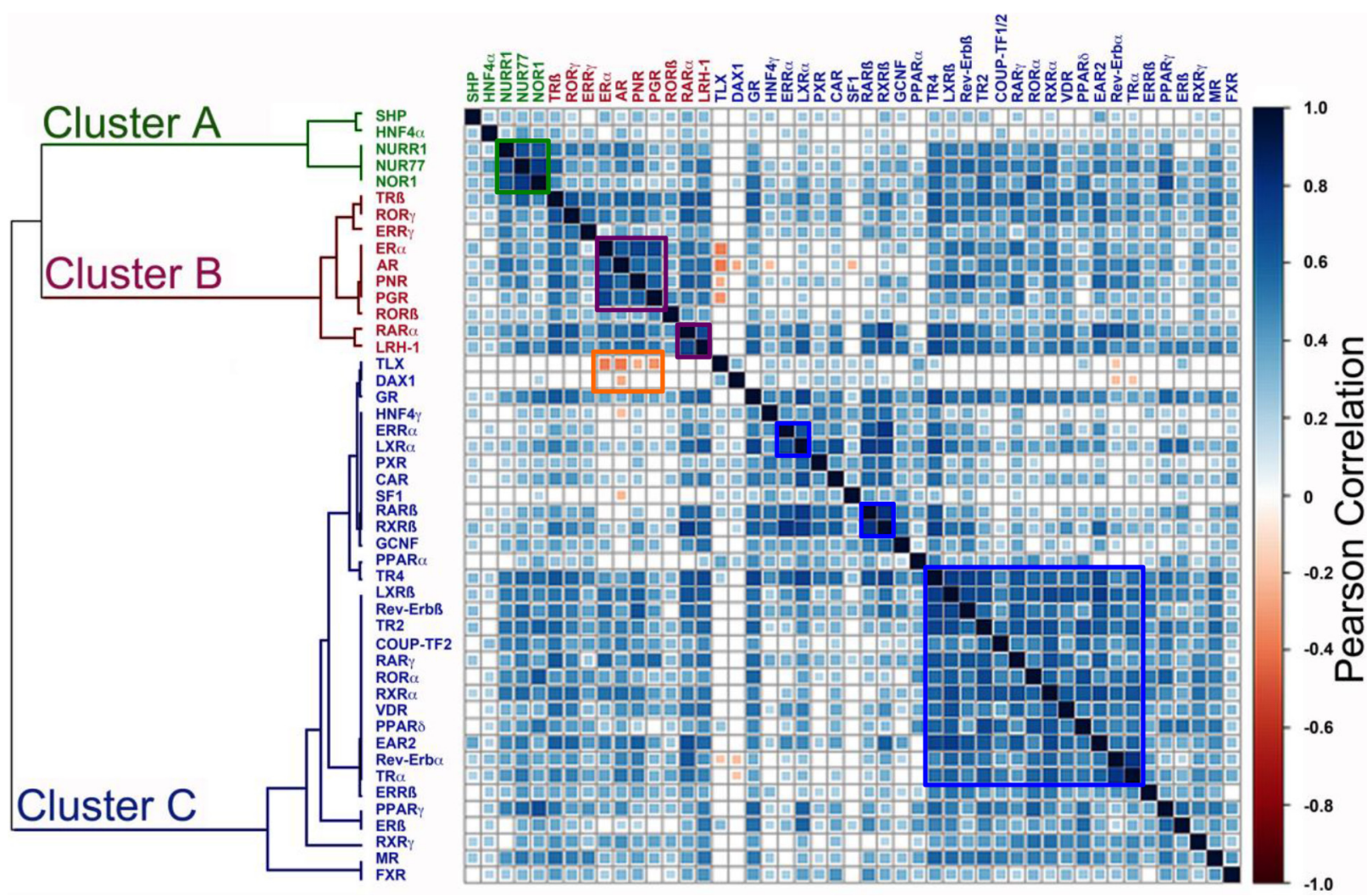

Figure 4: Pairwise Pearson Correlation Coefficient (PCC) analysis identifies NRs whose expression is positively or negatively associated with ER $\boldsymbol{\alpha}$ expression. A. Positive correlations (of 1 for self-comparisons) are depicted in blue, colour intensity reflecting the value of the correlation. The highest positive correlation value was 0.79 . Negative associations are shown in red, with the colour intensity increasing with greater negative correlation, the greatest negative value being 0.37 .

and METABRIC $(\mathrm{HR}=1.32(1.01-1.71), p=0.041)$ series (Figure 5). Our analyses also showed that TLX is predominantly expressed in poor prognosis, ER $\alpha$-negative breast cancers. Intriguingly, however, in these tumours, high expression of TLX in the absence of ER $\alpha$ is related to better survival, as seen in ER $\alpha$-negative $(\mathrm{HR}=0.69$ $(0.48-0.99), p=0.048)$ and the PAM50 basal subtype $(\mathrm{HR}=0.58(0.37-0.93), p=0.023)$.

\section{TLX regulates morphology, growth and invasive behaviour of triple-negative breast cancer cells}

Our analyses highlight a potentially significant role for TLX in triple-negative and/or basal subtype breast cancer. Only $33 \%$ of ER $\alpha$ and/or HER2 positive breast cancer cell lines expressed TLX, compared with $60 \%$ of the triplenegative lines (Figure 6B). The role of TLX in triple-negative breast cancer was evaluated using MDA-MB-157 cells, which had the highest TLX expression in the breast cancer cell line panel. RNAi-mediated TLX knockdown clearly inhibited proliferation in MDA-MB-157 cells, an effect that was observed with three independent siRNAs (Figure 7A, B). TLX knockdown similarly inhibited the growth of another triple-negative cell line, MDA-MB-468, which expresses moderate levels of TLX. All three TLX siRNAs failed to affect the growth of two lines that do not express TLX (BT20, JIMT1), arguing against off-target effects being responsible for the growth effects due to these siRNAs observed in the TLX expressing lines.

The invasive capacity of both lines was also markedly reduced following TLX silencing (Figure 7C), accompanied by significant inhibition in expression of epithelial-mesenchymal cell transition (EMT) markers such as MMP7, MMP9, vimentin and E-cadherin (Figure 7D). Since EMT can be associated with stem cell enrichment in breast cancer cells, we investigated the role of TLX on characteristics associated with breast cancer stem cells by investigating aldehyde dehydrogenase 1 (ALDH1) activity. TLX siRNA resulted in reduced expression of ALDHA1 and activity, determined using the Aldefluor assay (Figure 7E, F). The mammosphere assay provides an in vitro method for quantifying stem cell activity and self-renewal [25]. TLX knockdown resulted in a significant reduction in mammosphere forming efficiency in both cell lines (Figure 7G). Ectopic expression of TLX in MDA-MB-231 cells. In agreement with the siRNA results, TLX expression promoted growth, invasion and mammosphere formation in MDAMB-231 cells (Figure 8), supporting the results of the TLX knockdown. 

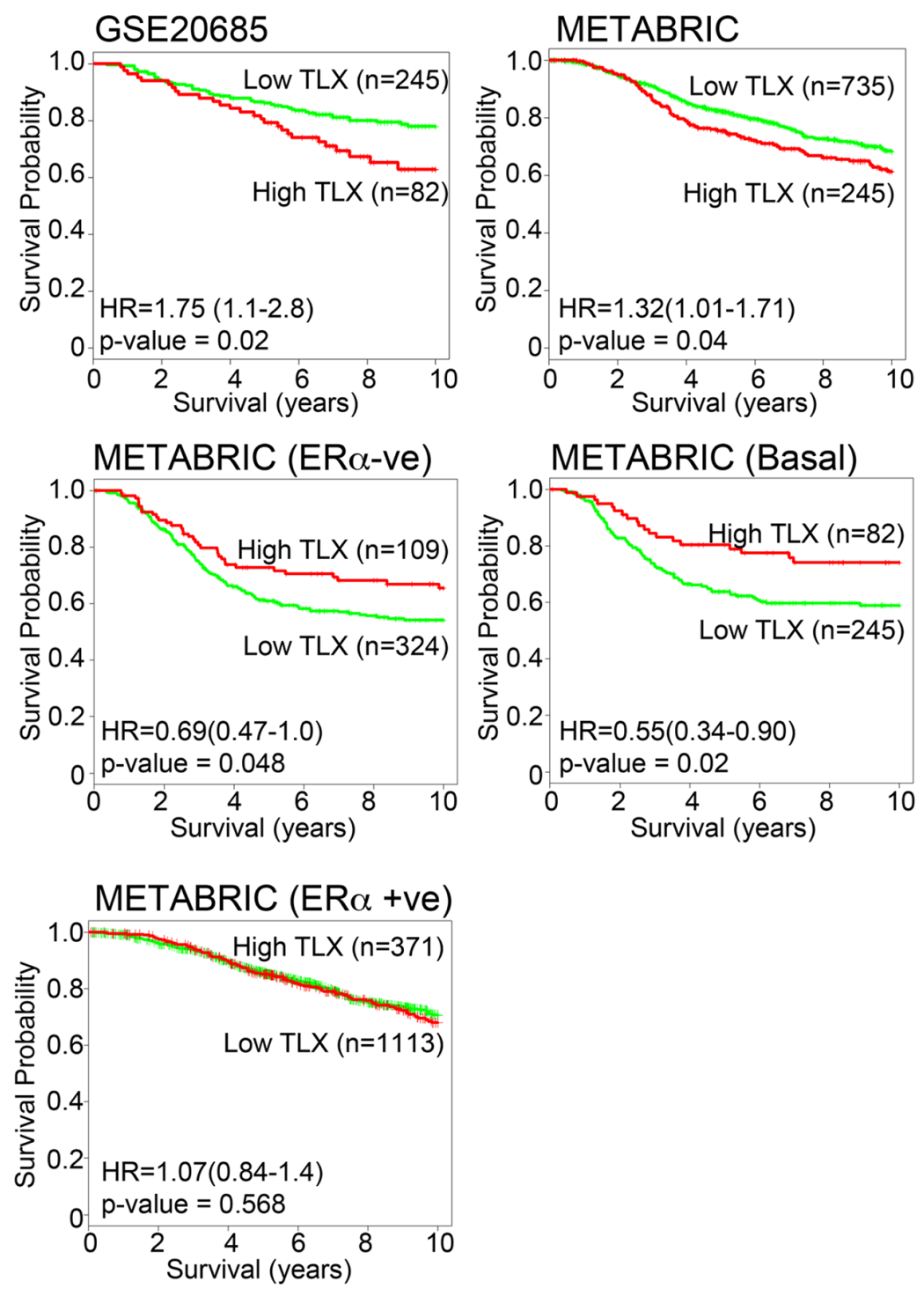

Figure 5: TLX expression is a marker of poor prognosis in breast cancer, but is associated with better prognosis in ERo-negative breast cancer. Kaplan-Meier survival plots for TLX expression in GSE20685 [23] and METABRIC [21] microarrays is shown for all tumours and for ER $\alpha$-negative and basal subtype tumours.

\section{DISCUSSION}

Given the important gene regulatory roles for NRs in cancer and their drugability, we performed unsupervised hierarchical consensus clustering to analyse real-time, quantitative RT-PCR gene expression data for NR expression from 128 breast cancers. This allowed a broad separation of tumours into two prognostic groups, where univariate analysis suggested that ER $\alpha$ and PGR, together with other NRs acted to affect survival differences. To further investigate this, we have used unsupervised consensus clustering analysis to define associations between NR gene expression in breast cancer and have found evidence for three gene clusters.

NR gene cluster A comprised SHP, HNF4 $\alpha$ and NR4A subfamily members. The NR4 subfamily members
Nurr1, Nur77 and NOR1 were highly expressed in most samples, irrespective of tumour subtype. By contrast, SHP and HNF $4 \alpha$ expression was low or absent in most tumours. Therefore, the co-clustering of these NRs is likely to be a reflection of a lack of differential expression across the range of tumours in our patient series. The high level expression of all three members of the NR4A receptors across the tumours is interesting, particularly in light of recent observations of increased expression of these NRs in breast cancer, compared with the normal breast [26]. NR4A receptors are important, albeit in a context-dependent manner, positive or negative regulators of cell survival and apoptosis [27]. Indeed, siRNA-mediated Nurr1 knockdown reduced growth of tumour xenografts [28], whereas Nur77 agonists inhibit MCF-7 cell proliferation and promote apoptosis [29]. However, another study has demonstrated 
A
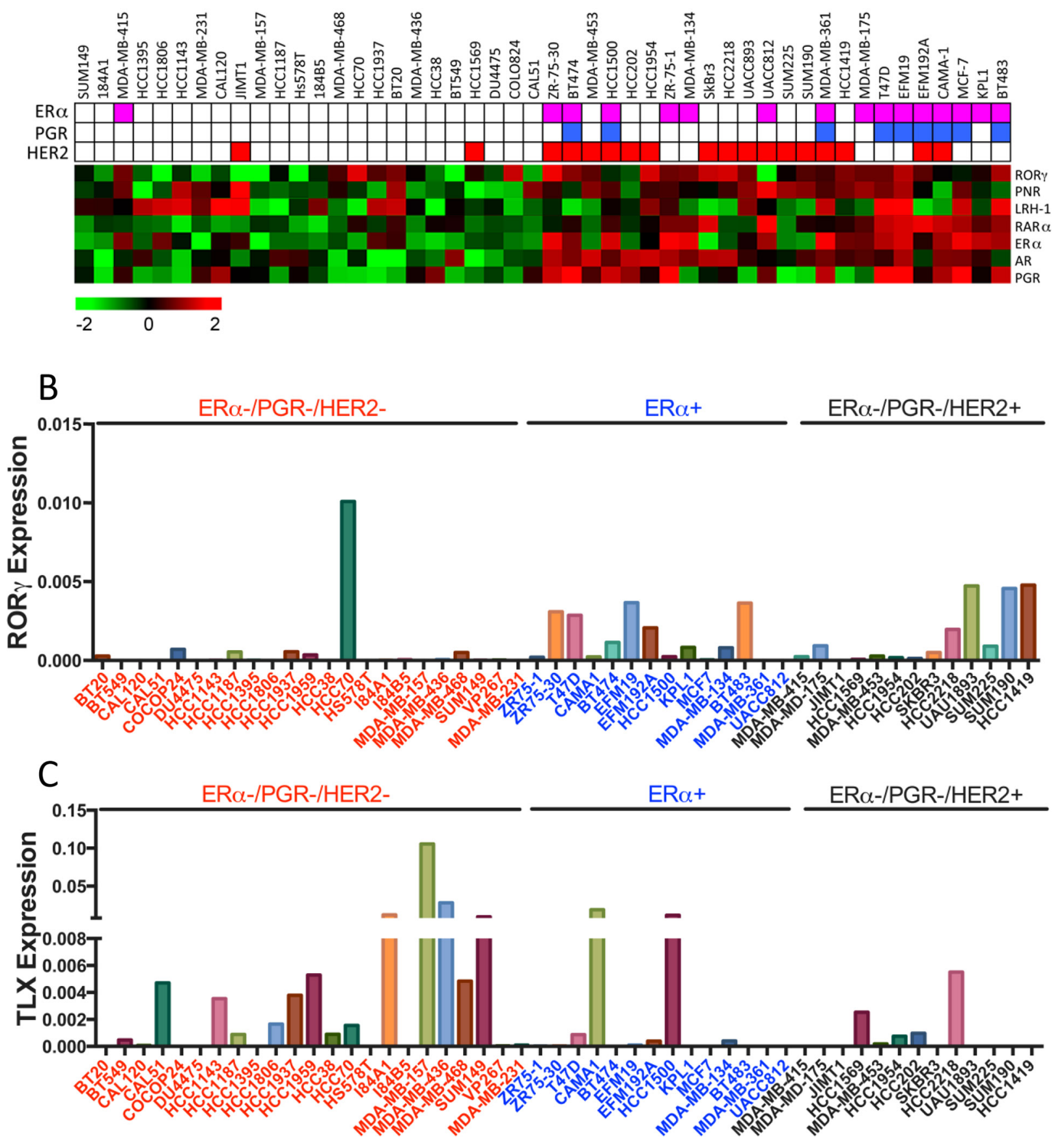

Figure 6: mRNA Expression of ROR $\gamma$ and TLX in Breast Cancer Cell Lines. A. Heat map representation of NR expression in breast cancer cell lines is shown. The ER $\alpha$, PGR and HER2 status of each cell line is also depicted. B, C. ROR $\gamma$ and TLX expression in breast cancer cell lines is shown relative to expression levels of GAPDH.

that Nur77 over-expression does not affect proliferation or apoptosis in a number of breast cancer cell lines; rather the migratory potential of breast cancer cell lines, as well as that of the immortalized MCF-10a cell line, was diminished [30]. Given the elevated expression of NR4A receptors in the majority of breast cancers, greater consideration of the function of these NRs and their potential as therapeutic targets and biomarkers in breast cancer is clearly warranted.

Gene cluster B contained ER $\alpha$ and a group of NRs previously associated with ER $\alpha$ in breast cancer, including PGR, AR, RAR $\alpha$, LRH-1, PNR, as well as TR $\beta$, ROR $\beta$, and ROR $\gamma$. We have referred to cluster B as the "ER $\alpha$ Cluster" 

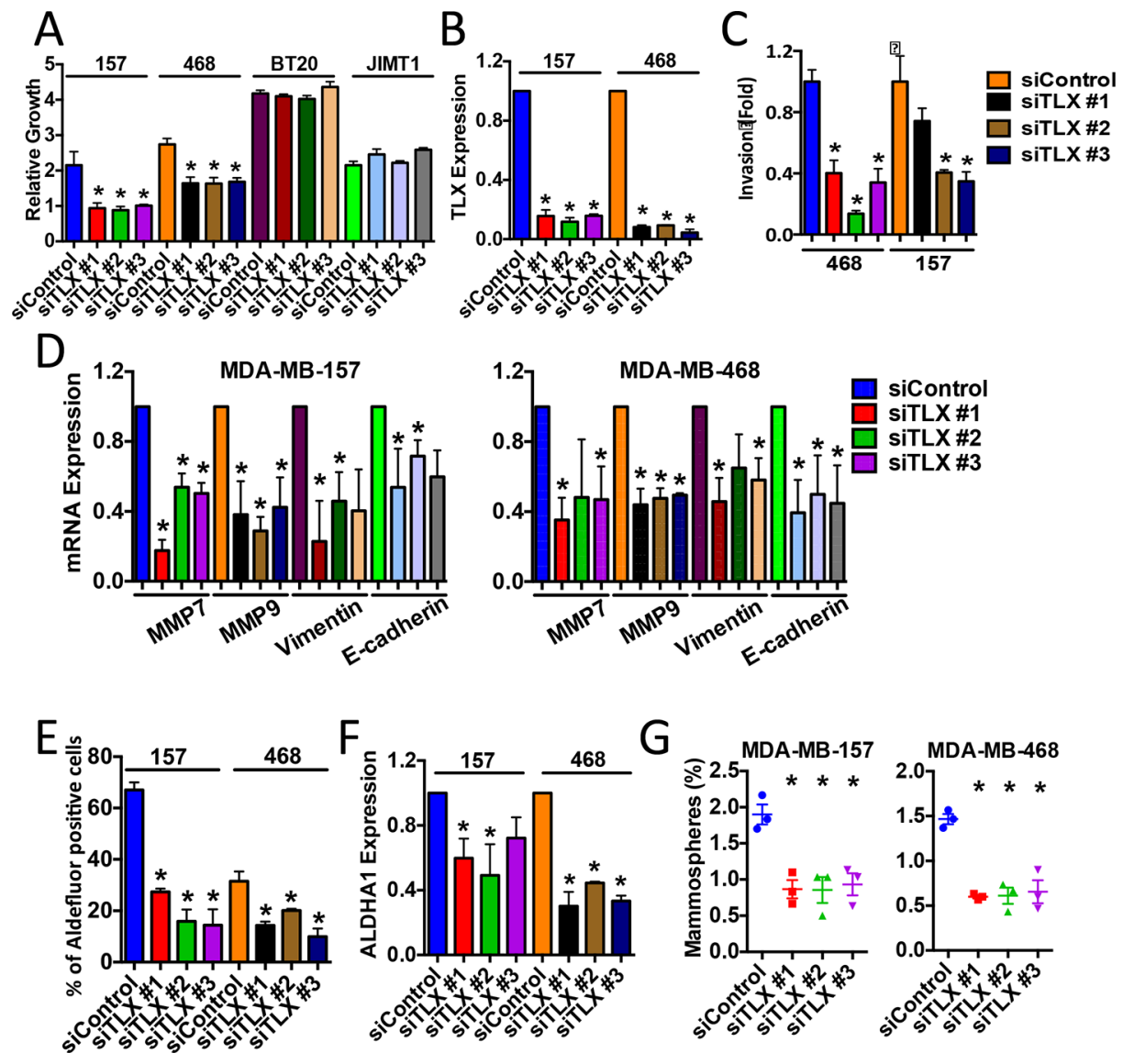

Figure 7: Targeted knockdown of TLX inhibits the growth of ERo-negative breast cancer cell lines. MDA-MB-157 and MDA-MB-468 cells were transfected with a non-targeting siRNA (siControl), or with three independent siRNAs for TLX. Each experiment included three replicates and three independent experiments were carried out. Error bars show standard errors of the mean, asterisks represent $p<0.05$, relative to the siControl. A. Cell number was assessed using the SRB assay 5 days following transfection. Growth is shown relative to the SRB values for day 0. B, D, F. Real-time RT-PCR was performed using RNA prepared from siRNA-transfected cells. mRNA expression was normalised to GAPDH expression. Bar charts represent mRNA levels compared to the siControl samples. C. Cells transfected with siRNAs were used in the transwell invasion assay. Bars represent number of invading cells. E. ALDH activity was determined using the Aldefluor assay. Bars show the percentage of Aldefluor-positive cells. G. Mammosphere forming efficiency (\%) was calculated as the number of mammospheres formed in 10 days, divided by the original number of single cells seeded.

and note that a key feature of this is a functional association with the estrogen response, as seen for the activity for ER $\alpha$, together with RAR $\alpha,[10,11]$, and more recently LRH-1, where we have found a functional co-operation between this NR and ER $\alpha$ through the use of common gene regulatory elements [12]. The association between ER $\alpha$ and ROR $\gamma$ gene expression in breast cancer and breast cancer cell lines is novel and would require further characterisation.

Gene Cluster C contained NRs whose activation has been associated with the inhibition of breast cancer cell growth, including GR, RAR $\beta$, RAR $\gamma$, ROR $\alpha$, PPAR $\gamma$ and VDR [16, 17], as well as ERß, TR2 and TR4 whose role in breast cancer may lie, at least in part, with their action in reducing or inhibiting ER $\alpha$ activity [31-33]. These NRs were not differentially expressed in ER $\alpha /$ PGR/HER2 subgroups, with the exception of RAR $\gamma$ whose expression appeared to be lower in HER2-positive than in HER2negative tumours, although statistical significance for association with HER2 status was not reached ( $p=0.076$ ). Other NRs in cluster $\mathrm{C}$ that have been implicated in breast cancer include ERR $\alpha$, which is highly expressed in our samples. ERR $\alpha$ regulates breast cancer cell proliferation in in vitro and in vivo models and genetic deletion of ERR $\alpha$ delays tumour formation in a transgenic model of HER2induced mammary tumourigenesis [34]. Transcriptomic studies have in particular highlighted the importance of ERR $\alpha$ and metabolism in breast cancer cells [35].

An important consideration is the fact that noncancer components, particularly the stroma, as well as lymphocyte infiltration may influence NR expression profiles, although NR expression in stroma and/or lymphocyte infiltration, may be of some importance in breast cancer progression. For example, LRH-1 drives aromatase expression in cancer-associated stroma [36], while lymphocyte infiltration is associated with good prognosis [37], and response to chemotherapy [38] in 
A

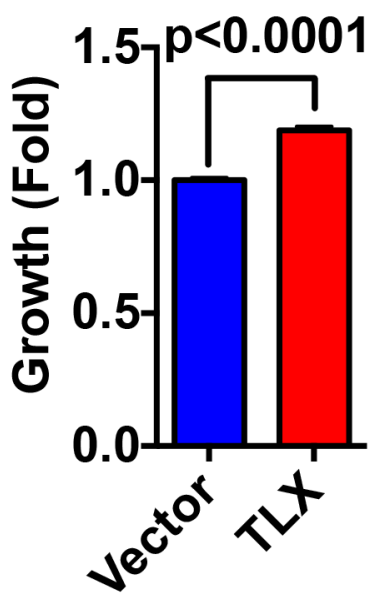

D

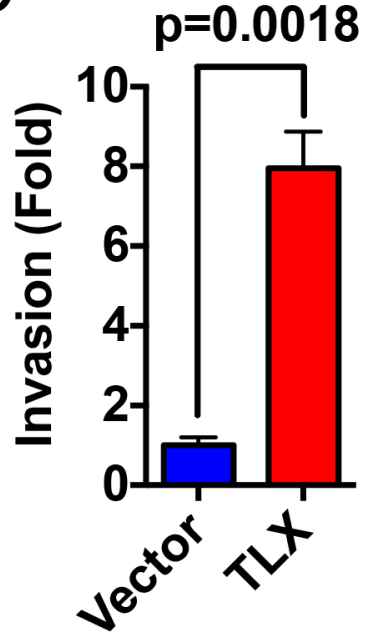

B

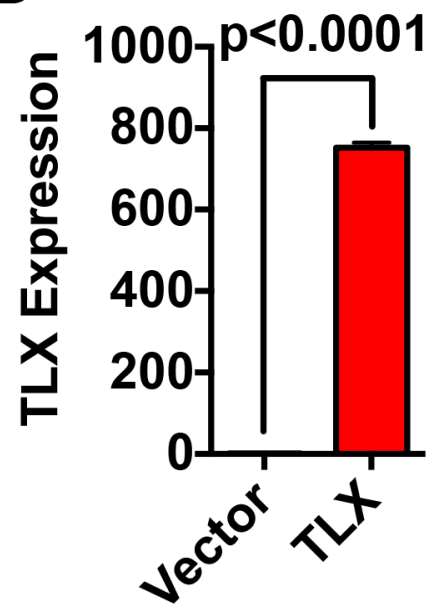

$\mathrm{E}$

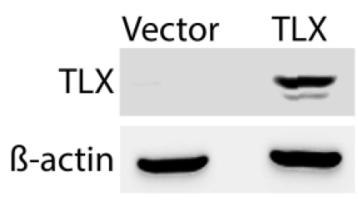

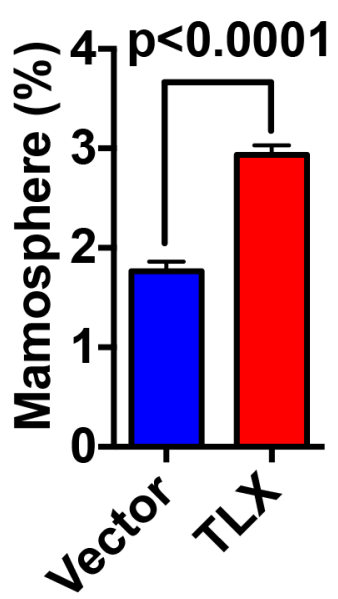

Figure 8: Ectopic expression of TLX promotes breast cancer cell growth, invasion and mammosphere formation. MDAMB-231 cells were transfected with TLX or with the vector control (pcDNA3). A. Cell number was assessed using the SRB assay 4 days following transfection. Growth is shown relative to the SRB values for the vector control $(n=3)$. B. Real-time RT-PCR was performed using RNA prepared from transfected MDA-MB-231 cells. mRNA expression was normalised to GAPDH expression. Bar charts represent mRNA levels compared to the vector control $(n=3)$. C. Protein lysates prepared from transfected cells were immunoblotted for TLX and B-actin. D. Cells transfected with TLX were used in the transwell invasion assay. Bars represent number of invading cells $(n=3)$. E. Mammosphere forming efficiency (\%) was calculated as the number of mammospheres formed in 10 days, divided by the original number of single cells seeded $(n=6)$.

ER $\alpha$-negative disease. Two major ROR $\gamma$ isoforms have been described, with ROR $\gamma \mathrm{t}$ being highly expressed in lymphocytes. Our expression NR profiling used a realtime assay that would detect $\operatorname{ROR} \gamma 1$, as well as the ROR $\gamma \mathrm{t}$ isoform. It is therefore possible that expression of the ROR $\gamma$ expression, presents expression in infiltrating lymphocytes, in addition to its expression in the cancer cells. In mitigation, expression profiling of NRs in diverse mouse tissues showed that SF-1 is one of 17 NRs that are expressed at moderate to high levels in tissues associated with the immune system (spleen, thymus) [39]. The near absence of SF-1 expression suggests that infiltrating lymphocytes only make up a minor component of the tumour cell population in our samples. Notwithstanding, we note that ROR $\gamma$ is expressed in many breast cancer cell lines and its expression is greater in ER $\alpha$-positive than In ER $\alpha$-negative cell lines, a relationship that is also observed in the tumour RNAs, as well as in microarray datasets. Further exploration of the functional importance of ROR $\gamma$ in breast cancer is therefore warranted.

Our analysis has also highlighted TLX as a gene of interest, since it is important in differentiating the two tumour clusters we have defined, where it is negatively associated with ER $\alpha$ mRNA expression and is associated with poor survival. Interestingly, TLX is one of a small number of genes expressed in breast cancer that predict for the presence of circulating tumour cells (CTC) [40]. Furthermore, tumours classified as CTC-positive in that 
study were more likely to be ER $\alpha$-negative. Low level/ absence of TLX expression in ER $\alpha$-positive breast cancer and elevated expression in ER $\alpha$-negative breast cancer may be due to the proposed different cellular origins of luminal and basal breast cancer sub-types, due to their origin in luminal and basal cells, respectively, or from different progenitor cells [41]. Interestingly, the most closely related NR to TLX is PNR, which promotes ER $\alpha$ expression in breast cancer cells through direct recruitment to the ER $\alpha$ gene promoter [19]. TLX and PNR both bind as monomers to very similar DNA motifs and given that TLX appears to function mainly as a transcriptional repressor [42], raising the intriguing possibility that TLX might repress ER $\alpha$ expression from the PNR binding site.

TLX regulates the proliferation and renewal potential of neural stem cells, where it acts as a transcriptional repressor through the recruitment of corepressors, histone deacetylases (HDAC) and lysinespecific histone demethylase (LSD1) [43, 44], whilst a recent study defined a role for TLX in the regulation of neural stem cell senescence [45]. p53 is frequently lost in gliomas and TLX over-expression promoted glioma formation in p53 null mice [46]. There is, however, no evidence for TLX function in tissues other than the brain and NR profiling in a panel of mouse tissues (which did not include the mammary gland) showed little or no expression in tissues other than in the CNS [39], although TLX expression has been reported in cell lines representative of some cancer types [47].

We have found that siRNA mediated inhibition of TLX expression in breast cancer cell lines leads to an inhibition of cell growth, invasive potential and cancer stem cell properties, supporting the conclusion that TLX is important in breast cancer. In neural stem cells, TLX represses the expression of negative regulators of cell cycle progression and proliferation, including p21, p57 and PTEN (60), as well as stimulating the Wnt/ß-catenin pathway through the direct activation of Wnt7a [48]. Our data demonstrate a functional role for TLX in breast cancer cells, although we did not observe de-repression of p21, p57 or PTEN expression (data not shown). Nor was expression of Wnt7A altered. This indicates that the action of TLX in breast cancer cells is mediated through target genes that are distinct from those implicated in neural stem cells. Other potentially relevant mechanisms of TLX function include the regulation of microRNAs, including the up-regulation of miR-9 [49], which has been implicated in breast cancer $[50,51]$. Clearly, as a potential target, the mechanism by which TLX functions in ER $\alpha$ negative breast cancer requires further investigation.

In summary, quantitative, real-time RT-PCR analysis of breast cancers revealed that the majority of NRs are expressed in breast cancer. Unsupervised hierarchical consensus clustering separated the tumours into clusters with prognostic significance. As expected, $\mathrm{ER} \alpha$ and PGR were key variables in the prognostic groups. These analyses NRs whose expression profiles are indicative of their importance in different breast cancer subtypes. However, our results do not preclude the importance of other NRs, which are widely expressed across breast cancer subtypes, for example COUPTFs, Nurr1/Nurr77/NOR1, RXRs, LXRs and PPARs. Indeed, a recent study mapping global binding sites for 24 nuclear receptors in the ER $\alpha$-positive MCF-7 breast cancer cell line [52] provides evidence for the coordinate binding of many NRs to target regions throughout the genome, as exemplified by PPAR $\delta$, which as our results show is widely expressed across breast cancer subtypes. Our clustering analysis does nevertheless identify the orphan nuclear receptor TLX as an important variable in breast cancer, which is preferentially expressed in ER $\alpha$ negative breast cancer where its importance is indicated by the prognostic significance of its expression and siRNA mediated growth inhibition and EMT. Secondly, we have uncovered a significant association between ER $\alpha$ and ROR $\gamma$ expression. Taken together, our profiling exercise describes two NRs whose function in breast cancer needs greater study.

\section{MATERIALS AND METHODS}

\section{Human breast cancer samples}

The patients presented with primary, operable breast cancer to the Dundee Cancer Centre between 1997 and 2012 and provided written, informed consent for research use of their tissues. Use of the clinical material and data was approved by the Tayside Tissue Bank under delegated authority from the Tayside Local Research Ethics Committee. ER $\alpha$, PGR and HER2 immunohistochemical staining and scoring were carried out as described [53]. For HER2, all cancers scoring "equivocal" $(2+)$ by IHC, were subjected to HER2 FISH analysis carried out using the PathVysion ${ }^{\mathrm{TM}}$ HER2 DNA probe kit (Vysis, Abbott Laboratories, Illinois, USA), with amplification of 2 fold or greater considered HER2 amplified. HER2 IHC positive (3+) cases, as well as FISH-positive HER2 IHC 2+ cases were scored as HER2-positive.

\section{Cell lines}

Authenticated cell lines obtained from American Type Culture Collection were cultured according to ATCC recommendations for RNA preparation. Cell lines were authenticated using the short tandem repeat (STR) profiling service (LGC Standards, UK) immediately prior to initiation of studies.

\section{RNA extraction}

Frozen breast tumour tissue (50 to $100 \mathrm{mg}$ ) was homogenized using TissueLyser (Qiagen) with stainless 
steel ball bearings $(5 \mathrm{~mm})$ in $0.7 \mathrm{ml}$ of Lysis/Binding Buffer (Ambion) and total RNA was isolated according to the manufacturer's instructions. Removal of contaminating DNA from the RNA preparation was performed using DNA-free ${ }^{\mathrm{TM}}$ kit (Ambion/Life Technologies) following the manufacturer's protocol. The concentration and purity of total RNA was assessed using a NanoDrop ${ }^{\mathrm{TM}} 1000$ spectrophotometer (Nanodrop Technologies, Wilmington, DE, USA).

\section{Reverse transcription}

$2.5 \mu \mathrm{g}$ of total RNA was reverse converted to cDNA in a volume of $20 \mu \mathrm{l}$ using RevertAid M-MuLV reverse transcriptase (Fermentas, York, UK), according to manufacturer's protocols. The reactions were carried out in the GeneAMP 9700 PCR machine (Applied Biosystems/Life Technologies, Paisley, UK) at $42^{\circ} \mathrm{C}$ for 1 hour, followed by 5 minutes at $95^{\circ} \mathrm{C}$.

\section{TaqMan low-density array (TLDA)}

384-well TLDA microfluidic cards were designed so as to include the Taqman real-time gene expression assays for 47 of the 48 human nuclear receptors that are included in the Taqman Human Nuclear Receptor Array (ABI cat. No.: 4379961). The Taqman assay for COUPTF1 (NR2F1) was excluded from our TLDA array as the manufacturer has flagged this assay as amplifying COUP-TF2 (NR2F2), in addition to NR2F1. No other pre-designed Taqman assays exclusively amplifying COUP-TF1 were available from ABI at the time. Also included in our TLDA design was an assay for the glycerol-2-phosphate dehydrogenase (GAPDH) gene, as a control. The TLDA cards were purchased from Applied Biosystems (Life Technologies, Paisley, UK). For each tumour sample, cDNA was diluted 1:10 in ribonucleasefree water. A total volume of $100 \mu \mathrm{l}$ reaction mixture, containing $50 \mu \mathrm{l}$ of diluted cDNA and $50 \mu \mathrm{l}$ of Taqman universal master mix was added to a TLDA fill reservoir. Each TLDA card was designed to assay 8 individual samples. The TLDA cards were then centrifuged twice at $1200 \mathrm{rpm}$ for 2 minutes, sealed and run on an ABI 7900HT real time instrument (Life Technologies, Paisley, UK).

\section{Expression analysis of TLDA data set}

TLDA card data were analysed using SDS2.2/RQ manager (ABI/Life Technologies). The quantification cycle threshold was kept constant and set at 0.15 across samples for data comparison, following manufacturer's instructions. The relative quantification to GAPDH expression was performed using DataAssist ${ }^{\mathrm{TM}} \mathrm{v} 3.0$ (ABI/ Life Technologies) and results exported to Microsoft excel for data processing. All values in the data set were log2 transformed for further statistical analysis, as has been described [39].

\section{Statistical analysis}

Statistical analyses were performed using R 2.15.1 software. Additional software packages (Consensus Cluster Plus, randomForest, corrplot, Hmisc, GMD, survival) were downloaded from the Comprehensive R Archive Network (CRAN).

Unsupervised consensus clustering was performed using R package ConsensusClusterPlus [18], using a mediancentered expression matrix. The procedure was carried out with 1000 repetitions, $80 \%$ item resampling (pItem), a maximum evaluated number of groups $(\mathrm{k})$ of 10 and use of an agglomerative hierarchical clustering algorithm with a distance metric given by one minus the Pearson correlation.

Random forest (RF) analysis was carried out using R package RandomForest [24]. The tumour cluster classification derived from consensus clustering served as a categorical factor for the RandomForest algorithm to generate a model using z-score transformed qRT-PCR dataset. The number of variables (NRs), randomly selected as candidates at each node was set to 7 and 5, 000, 10,000,20, 000 or 50,000 trees were grown to reach tree numbers at which classification error reached stability. The default values were used for the remaining parameters throughout the analysis.

The consensus clustering heatmap was generated using the heatmap. 3 code provided in the GMD package [54]. The dendrogram (clustering tree) for tumour and NR clustering were directly extracted from the consensus clustering analysis. For visualization, the expression data were normalized using median centred approach.

Pairwise Pearson Correlation Coefficient (PCC) analysis of NR in tumours was computed using Hmisc package. The resulting correlation coefficient and the matrix of $p$-value data were used as input to plot the correlation matrix graph using corrplot.

Breast cancer specific survival was estimated using $\mathrm{R}$ package survival [55] with the non-parametric product limit method (Kaplan-Meier). Continuous data were categorized into high expression or low expression, based on lower/upper quartile cut offs. Univariate Cox proportional hazards regression were used for examination of risk factors and given with corresponding hazard ratios (HR) and $95 \%$ confidence intervals. A $p$-value $<0.05$ was considered as significant and all $p$-values were two tailed.

\section{Gene expression microarray data}

GSE20685 was downloaded from Gene Expression Omnibus (GEO) [23]. The TCGA breast dataset was downloaded from The Cancer Genome Atlas Data Portal [22]. The METABRIC microarray data have been reported previously [21].

\section{RNA interference}

BT20, JIMT1, MDA-MB-157 and MDA-MB-468 cells were cultured in Dulbecco's modified Eagle's medium 
(DMEM) containing 10\% fetal calf serum (FCS). Cells were transfected with double-stranded RNA oligonucleotides using the Lipofectamine RNAiMax reverse transfection method (Invitrogen, UK), as described previously [12]. TLX siRNA \#1 (s14200), \#2 (s14201), \#3 (s14202) and control siRNA (4390846) were purchased from Ambion. RNA was prepared 48 hours following transfection and real-time RTPCR was performed, as described above. Real-time assays for TLX (Hs01128417_m1), ALDH1A1 (Hs00946916_m1), MMP7 (Hs01042796_m1), MMP9 (Hs00234579_m1), vimentin (Hs00185584_m1), E-cadherin (CDH1, Hs01023894_m1) and GAPDH (Hs99999905_m1) were purchased from ABI. Cell growth was determined using the sulphorhodamine B (SRB) assay, as described previously [12]. The transwell cell invasion assay, mammosphere culture and determination of ALDH activity were carried out as previously described [56].

\section{TLX transfection}

MDA-MB-231 cells were cultured in Dulbecco's modified Eagle's medium (DMEM) containing 10\% fetal calf serum (FCS). Cells were transfected with a FLAGtagged TLX expression plasmid [57] using Fugene HD (Promega, UK), as described previously [12].

\section{ACKNOWLEDGMENTS}

We thank the Tayside Tissue Bank for providing the patient samples used in this study. Drs Keiko Funa and Akiyoshi Uemura kindly provided the TLX plasmid. We are grateful to Dr Luca Magnani and Charlotte Bevan for helpful discussions.

\section{CONFLICTS OF INTEREST}

The authors declare no conflicts of interest.

\section{GRANT SUPPORT}

The Department of Health funded Imperial College Medicine Centre (ECMC) (no grant number) and the National Institute for Health Research (NIHR) Biomedical Research Centre (no grant number). Support was provided by Cancer Research UK [C37/A9335] and the Breast Cancer Campaign [2011NovPR31].

\section{REFERENCES}

1. Ferlay J, Steliarova-Foucher E, Lortet-Tieulent J, Rosso S, Coebergh JW, Comber H, Forman D, Bray F. Cancer incidence and mortality patterns in Europe: estimates for 40 countries in 2012. Eur J Cancer. 2013; 49:1374-1403.

2. Cuzick J, Sestak I, Baum M, Buzdar A, Howell A, Dowsett M, Forbes JF. Effect of anastrozole and tamoxifen as adjuvant treatment for early-stage breast cancer: 10-year analysis of the ATAC trial. The lancet oncology. 2010; $11: 1135-1141$.

3. Ali S, Coombes RC. Endocrine-responsive breast cancer and strategies for combating resistance. Nature reviews Cancer. 2002; 2:101-112.

4. Johnston SR, Dowsett M. Aromatase inhibitors for breast cancer: lessons from the laboratory. Nature reviews Cancer. 2003; 3:821-831.

5. Chawla A, Repa JJ, Evans RM, Mangelsdorf DJ. Nuclear receptors and lipid physiology: opening the X-files. Science. 2001; 294:1866-1870.

6. Moore JT, Collins JL, Pearce KH. The nuclear receptor superfamily and drug discovery. ChemMedChem. 2006; 1:504-523.

7. Patani N, Martin LA, Dowsett M. Biomarkers for the clinical management of breast cancer: international perspective. International journal of cancer Journal international du cancer. 2013; 133:1-13.

8. Chlebowski RT, Kuller LH, Prentice RL, Stefanick ML, Manson JE, Gass M, Aragaki AK, Ockene JK, Lane DS, Sarto GE, Rajkovic A, Schenken R, Hendrix SL, Ravdin PM, Rohan TE, Yasmeen S, et al. Breast cancer after use of estrogen plus progestin in postmenopausal women. The New England journal of medicine. 2009; 360:573-587.

9. Klijn JG, Setyono-Han B, Foekens JA. Progesterone antagonists and progesterone receptor modulators in the treatment of breast cancer. Steroids. 2000; 65:825-830.

10. Hua S, Kittler R, White KP. Genomic antagonism between retinoic acid and estrogen signaling in breast cancer. Cell. 2009; 137:1259-1271.

11. Ross-Innes CS, Stark R, Holmes KA, Schmidt D, Spyrou C, Russell R, Massie CE, Vowler SL, Eldridge M, Carroll JS. Cooperative interaction between retinoic acid receptoralpha and estrogen receptor in breast cancer. Genes \& development. 2010; 24:171-182.

12. Lai CF, Flach KD, Fox SP, Ottaviani S, Thiruchelvam PT, Kyle FJ, Thomas RS, Launchbury R, Hua H, Callaghan HB, Carroll JS, Coombes RC, Zwart W, Buluwela L, Ali S. Co-regulated gene expression by estrogen receptor-a and liver receptor homolog-1 is a feature of the estrogen response in breast cancer cells. Nucleic acids research. 2013; 41:10228-10240.

13. Peters AA, Buchanan G, Ricciardelli C, Bianco-Miotto T, Centenera MM, Harris JM, Jindal S, Segara D, Jia L, Moore NL, Henshall SM, Birrell SN, Coetzee GA, Sutherland RL, Butler LM, Tilley WD. Androgen receptor inhibits estrogen receptor-alpha activity and is prognostic in breast cancer. Cancer research. 2009; 69:6131-6140.

14. Farmer P, Bonnefoi H, Becette V, Tubiana-Hulin M, Fumoleau P, Larsimont D, Macgrogan G, Bergh J, Cameron D, Goldstein D, Duss S, Nicoulaz AL, Brisken C, Fiche M, Delorenzi M, Iggo R. Identification of molecular 
apocrine breast tumours by microarray analysis. Oncogene. 2005; 24:4660-4671.

15. Robinson JL, Macarthur S, Ross-Innes CS, Tilley WD, Neal DE, Mills IG, Carroll JS. Androgen receptor driven transcription in molecular apocrine breast cancer is mediated by FoxA1. The EMBO journal. 2011; 30:3019-3027.

16. Conzen SD. Minireview: nuclear receptors and breast cancer. Mol Endocrinol. 2008; 22:2215-2228.

17. Riggins RB, Mazzotta MM, Maniya OZ, Clarke R. Orphan nuclear receptors in breast cancer pathogenesis and therapeutic response. Endocrine-related cancer. 2010; 17:R213-231.

18. Wilkerson MD, Hayes DN. ConsensusClusterPlus: a class discovery tool with confidence assessments and item tracking. Bioinformatics. 2010; 26:1572-1573.

19. Park YY, Kim K, Kim SB, Hennessy BT, Kim SM, Park ES, Lim JY, Li J, Lu Y, Gonzalez-Angulo AM, Jeong W, Mills GB, Safe S, Lee JS. Reconstruction of nuclear receptor network reveals that NR2E3 is a novel upstream regulator of ESR1 in breast cancer. EMBO molecular medicine. 2012; 4:52-67.

20. Ariazi EA, Clark GM, Mertz JE. Estrogen-related receptor alpha and estrogen-related receptor gamma associate with unfavorable and favorable biomarkers, respectively, in human breast cancer. Cancer research. 2002; 62:6510-6518.

21. Curtis C, Shah SP, Chin SF, Turashvili G, Rueda OM, Dunning MJ, Speed D, Lynch AG, Samarajiwa S, Yuan Y, Graf S, Ha G, Haffari G, Bashashati A, Russell R, McKinney S, et al. The genomic and transcriptomic architecture of 2, 000 breast tumours reveals novel subgroups. Nature. 2012; 486:346-352.

22. The_Cancer_Genome_Atlas_Network. Comprehensive molecular portraits of human breast tumours. Nature. 2012; 490:61-70.

23. Kao KJ, Chang KM, Hsu HC, Huang AT. Correlation of microarray-based breast cancer molecular subtypes and clinical outcomes: implications for treatment optimization. BMC cancer. 2011; 11:143.

24. Breiman L. Random Forests. Machine Learning. 2001; 45:5-32.

25. Ponti D, Costa A, Zaffaroni N, Pratesi G, Petrangolini G, Coradini D, Pilotti S, Pierotti MA, Daidone MG. Isolation and in vitro propagation of tumorigenic breast cancer cells with stem/progenitor cell properties. Cancer research. 2005; 65:5506-5511.

26. Muscat GE, Eriksson NA, Byth K, Loi S, Graham D, Jindal S, Davis MJ, Clyne C, Funder JW, Simpson ER, Ragan MA, Kuczek E, Fuller PJ, Tilley WD, Leedman PJ, Clarke CL. Research resource: nuclear receptors as transcriptome: discriminant and prognostic value in breast cancer. Mol Endocrinol. 2013; 27:350-365.

27. Maxwell MA, Muscat GE. The NR4A subgroup: immediate early response genes with pleiotropic physiological roles. Nuclear receptor signaling. 2006; 4:e002.
28. Llopis S, Singleton B, Duplessis T, Carrier L, Rowan B, Williams C. Dichotomous roles for the orphan nuclear receptor NURR1 in breast cancer. BMC cancer. 2013; 13:139.

29. Chintharlapalli S, Burghardt R, Papineni S, Ramaiah S, Yoon K, Safe S. Activation of Nur77 by selected 1, 1-Bis(3'-indolyl)-1-(p-substituted phenyl)methanes induces apoptosis through nuclear pathways. The Journal of biological chemistry. 2005; 280:24903-24914.

30. Alexopoulou AN, Leao M, Caballero OL, Da Silva L, Reid L, Lakhani SR, Simpson AJ, Marshall JF, Neville AM, Jat PS. Dissecting the transcriptional networks underlying breast cancer: NR4A1 reduces the migration of normal and breast cancer cell lines. Breast cancer research: BCR. 2010; 12:R51.

31. Thomas C, Gustafsson JA. The different roles of ER subtypes in cancer biology and therapy. Nature reviews Cancer. 2011; 11:597-608.

32. Shyr CR, Hu YC, Kim E, Chang C. Modulation of estrogen receptor-mediated transactivation by orphan receptor TR4 in MCF-7 cells. The Journal of biological chemistry. 2002; 277:14622-14628.

33. Hu YC, Shyr CR, Che W, Mu XM, Kim E, Chang C. Suppression of estrogen receptor-mediated transcription and cell growth by interaction with TR2 orphan receptor. The Journal of biological chemistry. 2002; 277:33571-33579.

34. Deblois G, Chahrour G, Perry MC, Sylvain-Drolet G, Muller WJ, Giguere V. Transcriptional control of the ERBB2 amplicon by ERRalpha and PGC-1beta promotes mammary gland tumorigenesis. Cancer research. 2010; 70:10277-10287.

35. Deblois G, Giguere V. Oestrogen-related receptors in breast cancer: control of cellular metabolism and beyond. Nature reviews Cancer. 2013; 13:27-36.

36. Chand AL, Herridge KA, Howard TL, Simpson ER, Clyne CD. Tissue-specific regulation of aromatase promoter II by the orphan nuclear receptor LRH-1 in breast adipose stromal fibroblasts. Steroids. 2011; 76:741-744.

37. Rody A, Holtrich U, Pusztai L, Liedtke C, Gaetje R, Ruckhaeberle E, Solbach C, Hanker L, Ahr A, Metzler D, Engels K, Karn T, Kaufmann M. T-cell metagene predicts a favorable prognosis in estrogen receptor-negative and HER2-positive breast cancers. Breast cancer research: BCR. 2009; 11:R15.

38. Loi S, Sirtaine N, Piette F, Salgado R, Viale G, Van Eenoo F, Rouas G, Francis P, Crown JP, Hitre E, de Azambuja E, Quinaux E, Di Leo A, Michiels S, Piccart MJ, Sotiriou C. Prognostic and predictive value of tumorinfiltrating lymphocytes in a phase III randomized adjuvant breast cancer trial in node-positive breast cancer comparing the addition of docetaxel to doxorubicin with doxorubicin-based chemotherapy: BIG 02-98. Journal of clinical oncology: official journal of the American Society of Clinical Oncology. 2013; 31:860-867. 
39. Bookout AL, Jeong Y, Downes M, Yu RT, Evans RM, Mangelsdorf DJ. Anatomical profiling of nuclear receptor expression reveals a hierarchical transcriptional network. Cell. 2006; 126:789-799.

40. Molloy TJ, Roepman P, Naume B, van't Veer LJ. A prognostic gene expression profile that predicts circulating tumor cell presence in breast cancer patients. PloS one. 2012; 7:e32426.

41. Weigelt B, Reis-Filho JS. Histological and molecular types of breast cancer: is there a unifying taxonomy? Nature reviews Clinical oncology. 2009; 6:718-730.

42. Benoit $\mathrm{G}$, Cooney A, Giguere V, Ingraham $\mathrm{H}$, Lazar M, Muscat G, Perlmann T, Renaud JP, Schwabe J, Sladek F, Tsai MJ, Laudet V. International Union of Pharmacology. LXVI. Orphan nuclear receptors. Pharmacological reviews. 2006; 58:798-836.

43. Sun G, Yu RT, Evans RM, Shi Y. Orphan nuclear receptor TLX recruits histone deacetylases to repress transcription and regulate neural stem cell proliferation. Proceedings of the National Academy of Sciences of the United States of America. 2007; 104:15282-15287.

44. Sun G, Alzayady K, Stewart R, Ye P, Yang S, Li W, Shi Y. Histone demethylase LSD1 regulates neural stem cell proliferation. Molecular and cellular biology. 2010; 30:1997-2005.

45. O'Loghlen A, Martin N, Krusche B, Pemberton H, Alonso MM, Chandler H, Brookes S, Parrinello S, Peters G, Gil J. The nuclear receptor NR2E1/TLX controls senescence. Oncogene. 2015; 34:4069-4077.

46. Zou Y, Niu W, Qin S, Downes M, Burns DK, Zhang CL. The nuclear receptor TLX is required for gliomagenesis within the adult neurogenic niche. Molecular and cellular biology. 2012; 32:4811-4820.

47. Holbeck S, Chang J, Best AM, Bookout AL, Mangelsdorf DJ, Martinez ED. Expression profiling of nuclear receptors in the NCI60 cancer cell panel reveals receptor-drug and receptor-gene interactions. Mol Endocrinol. 2010; 24:1287-1296.

48. Qu Q, Sun G, Li W, Yang S, Ye P, Zhao C, Yu RT, Gage FH, Evans RM, Shi Y. Orphan nuclear receptor TLX activates Wnt/beta-catenin signalling to stimulate neural stem cell proliferation and self-renewal. Nature cell biology. 2010; 12:31-40. sup pp 31-39.

49. Zhao C, Sun G, Li S, Shi Y. A feedback regulatory loop involving microRNA-9 and nuclear receptor TLX in neural stem cell fate determination. Nature structural \& molecular biology. 2009; 16:365-371.

50. Selcuklu SD, Donoghue MT, Rehmet K, de Souza Gomes M, Fort A, Kovvuru P, Muniyappa MK, Kerin MJ, Enright AJ, Spillane C. MicroRNA-9 inhibition of cell proliferation and identification of novel miR-9 targets by transcriptome profiling in breast cancer cells. The Journal of biological chemistry. 2012; 287:29516-29528.

51. Krell J, Frampton AE, Jacob J, Pellegrino L, RocaAlonso L, Zeloof D, Alifrangis C, Lewis JS, Jiao LR, Stebbing J, Castellano L. The clinico-pathologic role of microRNAs miR-9 and miR-151-5p in breast cancer metastasis. Molecular diagnosis \& therapy. 2012; 16:167-172.

52. Kittler R, Zhou J, Hua S, Ma L, Liu Y, Pendleton E, Cheng C, Gerstein M, White KP. A comprehensive nuclear receptor network for breast cancer cells. Cell reports. 2013; 3:538-551.

53. Purdie CA, Baker L, Ashfield A, Chatterjee S, Jordan LB, Quinlan P, Adamson DJ, Dewar JA, Thompson AM. Increased mortality in HER2 positive, oestrogen receptor positive invasive breast cancer: a population-based study. British journal of cancer. 2010; 103:475-481.

54. Zhao X, Valen E, Parker BJ, Sandelin A. Systematic clustering of transcription start site landscapes. PloS one. 2011; 6:e23409.

55. Therneau TM, Grambsch PM. Modeling survival data: extending the Cox Model. Springer. 2000.

56. Lombardo Y, Filipovic A, Molyneux G, Periyasamy M, Giamas G, Hu Y, Trivedi PS, Wang J, Yague E, Michel L, Coombes RC. Nicastrin regulates breast cancer stem cell properties and tumor growth in vitro and in vivo. Proceedings of the National Academy of Sciences of the United States of America. 2012; 109:16558-16563.

57. Zeng ZJ, Johansson E, Hayashi A, Chavali PL, Akrap N, Yoshida T, Kohno K, Izumi H, Funa K. TLX controls angiogenesis through interaction with the von HippelLindau protein. Biology open. 2012; 1:527-535. 